Florida International University FIU Digital Commons

$3-27-2015$

\title{
Leaf Functional Traits and Forest Structure of Tropical Dry Forest Species Along a Rainfall Gradient in Florida and Puerto Rico
}

Ramon L. Salazar II

Florida International University, rsala010@fiu.edu

DOI: $10.25148 /$ etd.FI15032197

Follow this and additional works at: https://digitalcommons.fiu.edu/etd

Part of the Environmental Sciences Commons

\section{Recommended Citation}

Salazar, Ramon L. II, "Leaf Functional Traits and Forest Structure of Tropical Dry Forest Species Along a Rainfall Gradient in Florida and Puerto Rico" (2015). FIU Electronic Theses and Dissertations. 1754.

https://digitalcommons.fiu.edu/etd/1754 


\title{
FLORIDA INTERNATIONAL UNIVERSITY
}

Miami, Florida

\section{LEAF FUNCTIONAL TRAITS AND FOREST STRUCTURE OF TROPICAL DRY FOREST SPECIES ALONG A RAINFALL GRADIENT IN FLORIDA AND PUERTO RICO}

\author{
A thesis submitted in partial fulfillment of the \\ requirements for the degree of \\ MASTER OF SCIENCE \\ in \\ ENVIRONMENTAL STUDIES \\ by
}

Ramón Salazar II

2015 
To: Dean Michael R. Heithaus

College of Arts and Sciences

This thesis, written by Ramón Salazar II, and entitled Leaf Functional Traits and Forest Structure of Tropical Dry Forest Species Along a Rainfall Gradient in Florida and Puerto Rico have approved in respect to style and intellectual content, is referred to you for judgment.

We have read this thesis and recommend that it be approved.

Skip J. Van Bloem

Steven F. Oberbauer

Krish Jayachandran, Co-Major Professor

Michael S. Ross, Co-Major Professor

Date of Defense: March 27, 2015

The thesis of Ramón Salazar II is approved.

Dean Michael R. Heithaus College of Arts and Sciences

Dean Dr. Lakshmi N. Reddi University Graduate School

Florida International University, 2015 


\section{DEDICATION}

I dedicate this thesis to my parents Leonidas Salazar-Ortiz and Ramón L. Salazar. Their unconditional love and support has been essential in every chapter of my life. I also dedicate this thesis to Ms. Olga Gonzalez, a high school teacher who sparked my interest in the field of environmental sciences. 


\section{ACKNOWLEDGMENT}

I wish to express my deepest gratitude to the members of my committee for their approachability, personal and professional support and guidance throughout the years as a graduate student. I could not have asked for a better team. Dr. Ross and Dr. Van Bloem contributed in a great way to the field logistics, experimental design, and interpretation of data for this project. Dr. Jay delivered much valuable advice on soil sampling and analysis, and provided the laboratory resources to complete this project. Dr. Oberbauer made important suggestions in regards to plant biological aspects and also provided important input to the thesis manuscript.

Many thanks to the staff of FIU Agrocology Program, especially Dr. Mahadev Bhat and Mrs. Stephany Alvarez-Ventura for supporting me through this ride and inspiring confidence to challenge myself in extra-curricular activities that greatly enriched my academic experience.

I am thankful to Dr. Pushpa Soti, Ms. Diana Johnson, Dr. Kateel Shetty, and Dr. Leonard Scinto for training and assisting me in the laboratory phase of the project. A big thanks goes to my friends Christian Rosario-Borrero and Adonis Alvarez for their valuable assistance out in the field. I am also grateful to the entire staff of the South Florida Terrestrial Ecosystems Lab for their kindness to my person and suggestions in many aspects of the project. Special thanks goes to Mrs. Sussana Stofella and Dr. Jay Sah for their statistical advice in this research project.

This work would have not been possible without the financial support of the United States Department of Agriculture, National Institute of Food and Agriculture National Needs Fellowship Program (Grant \#2011-38420-20053). 


\begin{abstract}
OF THE THESIS
LEAF FUNCTIONAL TRAITS AND FOREST STRUCTURE OF TROPICAL DRY

FOREST SPECIES ALONG A RAINFALL GRADIENT IN FLORIDA AND

PUERTO RICO

by

Ramón Salazar II
\end{abstract}

Florida International University, 2015

Miami, Florida

Professor Michael S. Ross, Co-Major Professor

Professor Krish Jayachandran, Co-Major Professor

This study examined how different rainfall regimes affect a set of leaf functional traits related to plant stress and forest structure in tropical dry forest (TDF) species on limestone substrate. One hundred fifty eight individuals of four tree species were sampled in six ecological sites in south Florida and Puerto Rico, ranging in mean annual rainfall from 858 to $1933 \mathrm{~mm} \mathrm{yr}^{-1}$. Leaf nitrogen content, specific leaf area (SLA), and $\mathrm{N}: \mathrm{P}$ ratio of evergreen species, but not deciduous species, responded positively to increasing rainfall. Phosphorus content was unaffected in both groups. Canopy height and basal area reached maxima of $10.3 \mathrm{~m}$ and $31.4 \mathrm{~m}^{2} \mathrm{ha}^{-1}$, respectively, at $1168 \mathrm{~mm}$ annual rainfall. Leaf traits reflected soil properties only to a small extent. This led us to the conclusion that water is a major limiting factor in TDF and some species that comprise TDF ecosystems are limited by nitrogen in limestone sites with less than $\sim 1012$ $\mathrm{mm}$ rainfall, but organismal, biological and/or abiotic forces other than rainfall control forest structure in moister sites. 


\section{TABLE OF CONTENTS}

CHAPTER

PAGE

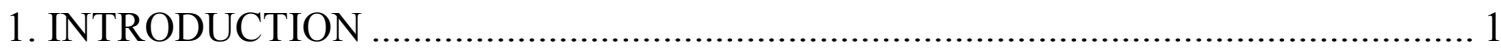

1.1 Caribbean tropical dry forest..................................................................... 1

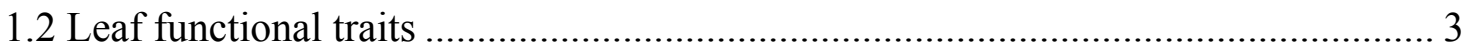

1.3 Soil moisture, nutrient availability, and the soil-plant relationship ...................... 6

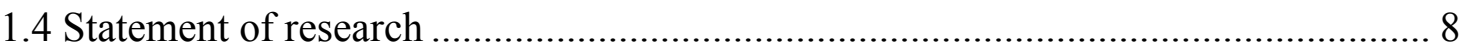

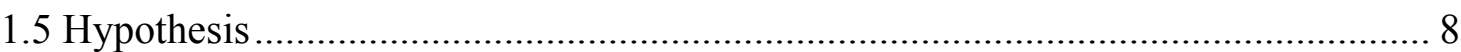

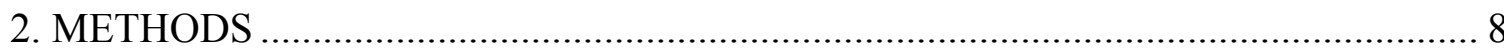

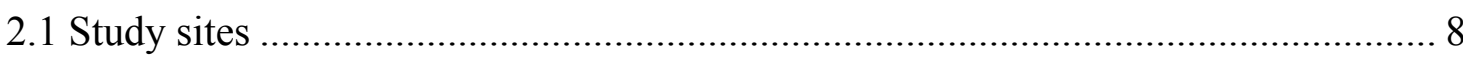

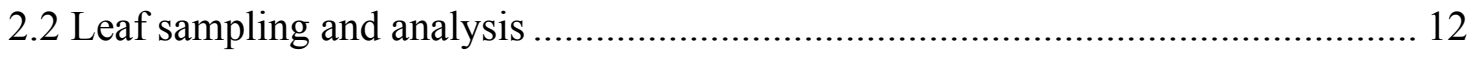

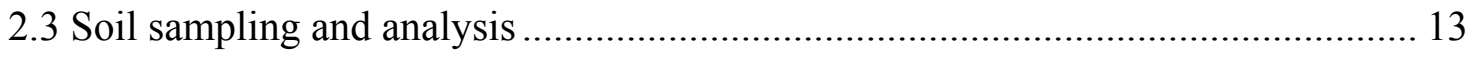

2.4 Forest structure data collection ............................................................... 14

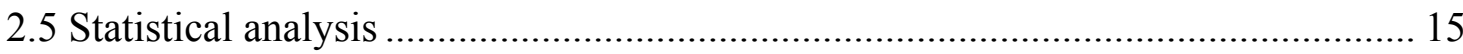

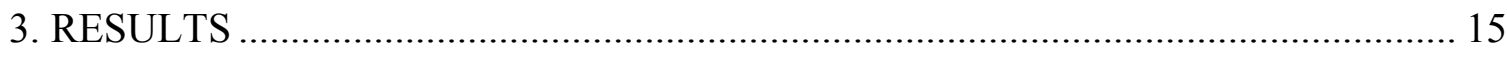

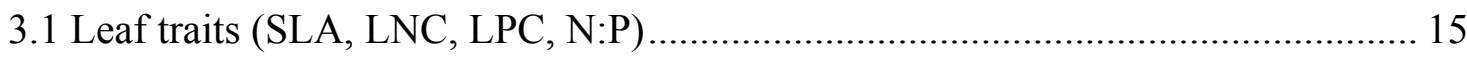

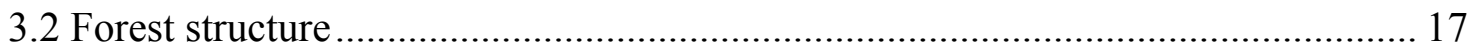

3.3 Soil properties and the relationships with leaf traits and structure ...................... 18

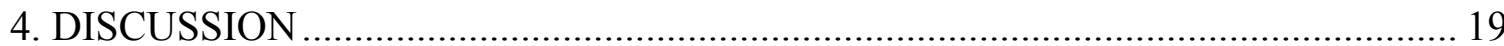

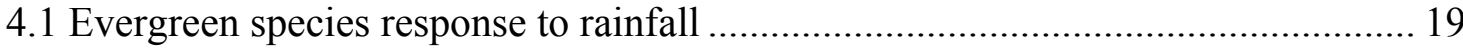

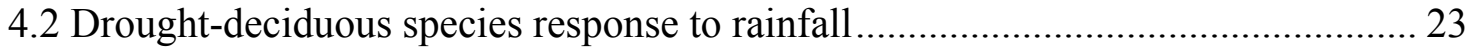

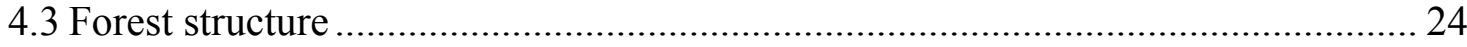

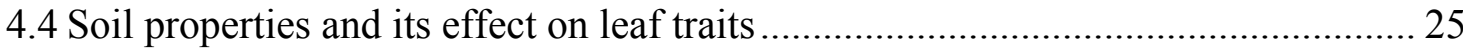

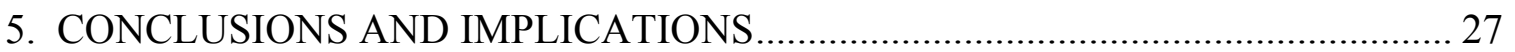

6. LITERATURE CITED ................................................................................ 30 


\section{LIST OF FIGURES}

FIGURE

PAGE

Figure 1: Map showing the location of Puerto Rico study sites ......................................39

Figure 2: Map showing the location of Florida study sites..........................................40

Figure 3: Scatterplot showing the effect of rainfall on specific leaf area ........................41

Figure 4: Scatterplot showing the effect of rainfall on leaf nitrogen content ...................42

Figure 5: Scatterplot showing the effect of rainfall on leaf phosphorus content ..............43

Figure 6: Scatterplot showing the effect of rainfall on leaf nitrogen to phosphorus ratio.44

Figure 7: Scatterplot showing the effect of rainfall on forest canopy height...................45

Figure 8: Scatterplot showing the effect of rainfall on basal area .................................46

Figure 9: Means plot for soil total nitrogen of ecosites ............................................47

Figure 10: Means plot for soil total phosphorus of ecosites .......................................48

Figure 11: Means plot for soil soluble reactive phosphorus of ecosites .........................49

Figure 12: Scatterplot showing the effect of rainfall on soil soluble reactive phosphorus

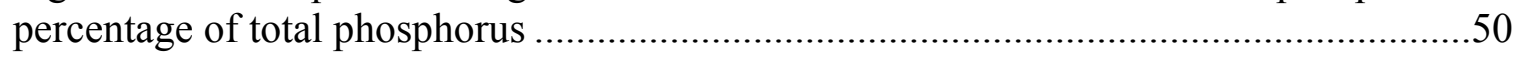

Figure 13: Scatterplot showing the effect of soil total nitrogen on specific leaf area .......51

Figure 14: Scatterplot showing the effect of soil total nitrogen on leaf nitrogen content .52

Figure 15: Scatterplot showing the effect of soil total phosphorus on leaf phosphorus

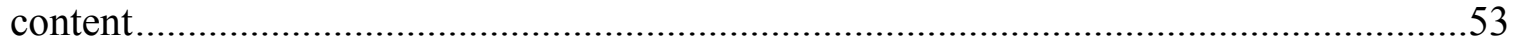

Figure 16: Scatterplot showing the effect of soil soluble reactive phosphorus on leaf phosphorus content 


\section{ABBREVIATIONS AND ACRONYMS}

$\begin{array}{ll}\text { Gram } & \mathrm{g} \\ \text { Hectare } & \text { ha } \\ \text { Leaf nitrogen : phosphorus ratio } & \mathrm{N}: \mathrm{P} \\ \text { Leaf nitrogen content } & \text { LNC } \\ \text { Leaf phosphorus content } & \text { LPC } \\ \text { Meters } & \mathrm{m} \\ \text { Milligram } & \mathrm{mg} \\ \text { Millimeters } & \mathrm{mm} \\ \text { Mole/molar } & \mathrm{mol} \\ \text { Organic Matter Content } & \text { OMC } \\ \text { Specific leaf area } & \text { SLA } \\ \text { Total nitrogen } & \text { TN } \\ \text { Total phosphorus } & \text { TP } \\ \text { Tropical dry forest } & \text { TDF }\end{array}$




\section{INTRODUCTION}

\subsection{Caribbean tropical dry forest}

The tropical dry forest (TDF) life zone comprises $39-42 \%$ of the world's tropical forest area (Brown \& Lugo 1982; Portillo-Quintero \& Sanchez-Asofeifa, 2010). Some authors consider TDF to be the most threatened of all tropical terrestrial ecosystems (Hoekstra et al. 2005; Vieira \& Scariot 2006). It is estimated that two-thirds of the natural extent of TDF in the Americas has been converted to other land uses. Nine percent $\left(46,839 \mathrm{~km}^{2}\right)$ of the present extent of Neotropical TDF is located in the Insular Caribbean, a UNESCO Biodiversity Hotspot area. A large proportion of this TDF is in Cuba $\left(79 \% ; 36,996 \mathrm{~km}^{2}\right)$. Some islands have experienced higher land use changes and only have a small fraction of its original TDF left (e.g., Puerto Rico: $\sim 5 \%$ ). A total of $10 \%$ of the Caribbean TDF is protected, $66 \%$ of this under a "protected area with sustainable use of natural resources" designation (IUCN Protected Area Category VI) while another $20 \%$ is categorized as "National Park" (IUCN Protected Area Category II, Portillo-Quintero \& Sanchez-Asofeifa 2010). Proper understanding of the ecosystem and its components is required for successful management and restoration activities. Nevertheless, current understanding and research efforts in TDF are well behind those of moist and wet forests.

The tropical dry forest develops in frost-free areas subject to $250-2000 \mathrm{~mm}$ mean annual rainfall, $>25^{\circ} \mathrm{C}$ mean annual temperature, and a dry season lasting from 3-8 months. The mean annual potential evapotranspiration is higher than rainfall, thus TDF is considered to be a water-limited ecosystem (Holdridge 1967; Ewel \& Whitmore 1973; Murphy et al. 1995; Sanchez-Asofeifa et al. 2005). 
Tropical deciduous and evergreen broadleaved tree species dominate the TDF. The Caribbean TDF structure is characterized by a short canopy of 3 to $12 \mathrm{~m}$, low basal area, few (1-2) canopy layers, and a high density of stems. The forest composition, structure, and function has been associated with multiple factors including: water limitation, duration of dry season, nutrient limitation, and natural and anthropogenic disturbances (e.g. strong winds, harvesting; Lugo \& Murphy 1986; Ross et al. 1992 \& 2010; Sanchez-Asofeifa et al. 2005; Ceccon 2006; Van Bloem et al. 2006; 2007)

A study in Guanica, Puerto Rico, showed a positive relationship between tree gross primary productivity and soil moisture availability (Lugo et al. 1978). A similar pattern of increasing forest canopy height along a rainfall gradient has also been described for TDF sites in the Florida Keys (Ross et al. 1992; Gillespie 2006). Other than rainfall, edaphic factors, i.e., soil texture, organic matter content, depth and parent material, play a fundamental role in determining soil moisture regime. As an example, a higher rate of net photosynthesis was reported for trees growing in deep soils in saddles when compared to trees growing in shallow soils on slopes (Lugo et al. 1978). Relationships among soil moisture regime, soil nutrient availability, and plant nutritional status have been demonstrated (Van de Driessche 1974; Struhar 2004; Gusewell 2004; Renteria et al. 2005).

In some settings, phosphorus (P) availability in soil is limiting to forest productivity and structure parameters (Jaramillo \& Sanford 1995; Lugo \& Murphy 1986; Redwine 2007). Approximately $50 \%$ of the dry forests in the world occur on nutrient poor soils (Ceccon et al. 2006). In the Caribbean, many of these forests grow on shallow soils developed over limestone substrate. Plant available phosphorus in these soils has 
been linked to (1) high soil calcium content, causing phosphorus to be in forms not available to plants, and to (2) limited soil solution/dissolution in the excessively drained substrate (Murphy et al. 1995). Therefore, higher soil moisture caused by increasing rainfall could be expected to have an alleviating effect on tree nutrient limitation.

On the basis of the information available, it is therefore reasonable to suggest that a significant increase in rainfall and nutrient availability will result in a forest stand with different structural attributes associated with greater productivity (i.e. canopy height, basal area, stem density); and consequently, a stand with different resources and ecological services, not only relevant to biodiversity but also to societal aspects. On the other hand, climatic models predict future changes in temperature, rainfall, and related climatic factors at the regional and local levels. Considering this information we designed a study to investigate how different rainfall regimes and soil properties affect a set of leaf functional traits related to plant stress and forest structure of TDF tree species in limestone areas.

\subsection{Leaf functional traits}

Leaf functional trait analysis is a useful tool in plant ecology and has played an important role in theories related to plant growth, plasticity, species co-existence, and ecosystem-level processes (Koerselman \& Meuleman 1996; Aerts \& Chapin 1999; Díaz \& Cabido 2001; Güsewell 2004; Kearney \& Porter 2006; McGill et al. 2006; Westoby \& Wright 2006; Chaturvedi et al. 2011). Plant species growing in different environments usually exhibit physiological and functional trait modifications in response to site specific

conditions. Specific leaf area (SLA), leaf nitrogen content (LNC), leaf phosphorus 
content (LPC), and leaf N:P ratio are traits that vary within and among species and are known to be related to plant acquisition and use of resources (Wright et al. 2004).

Specific leaf area (SLA) refers to the leaf surface area per unit of dry mass $\left(\mathrm{mm}^{2} / \mathrm{mg}\right)$. Multiple studies have shown SLA and leaf area (LA) to decrease with decreasing moisture availability at the community level. The phenomenon is commonly described as sclerophylly; and besides its relation with water, it has also been linked to low nutrient sites (Medina et al. 1990; Cunningham et al. 1999; Fonseca et al. 2000; McDonald et al. 2003; Poorter 2009). This data has led researchers to ask whether sclerophyllous leaves in Puerto Rican dry forest are an expression of water stress, low nutrient availability, or the combined effect of both (Murphy et al. 1995). Other findings in line with this theory are species with high SLA values often exhibit high rates of photosynthesis and growth while species with low SLA values display lower rates; and SLA and leaf life span are negatively correlated (Hamman 1979; Reich et al., 1997; Lambrecht \& Dawson, 2007; Poorter 2009; Chaturvedi 2011). However, several studies have indicated that community-level variation may not always represent species-level trait variation (Fonseca et al. 2000; Ackerly et al. 2002).

Nitrogen and phosphorus are essential in plant enzymatic activity and cell energy transfer and are generally considered the main growth-limiting nutrients for plants in natural environments. Leaf nutrient concentration has been suggested as an indicator of plant nutritional status and as an alternative means to examine soil nutrient availability (Van de Driessche, 1974; Gusewell 2004). A leaf nitrogen to phosphorus mass ratio of 10 has been suggested as optimal for plant growth in shrub and tree species (Van de Driessche, 1974; Ingestad, 1979; Lajtha \& Klein, 1988; Aerts \& Chapin, 1999). Most 
studies determining nutrient limitation in terrestrial vegetation have employed the N:P values proposed by Koerselman \& Meuleman (1996) in a study restricted to fertilization experiments on European wetland species. That study concluded that at leaf per unit mass $\mathrm{N}: \mathrm{P}$ ratios $>16(>36$ molar), plants are limited by $\mathrm{P}$ and at ratios $<14(<32$ molar) plants are limited by $\mathrm{N}$. Leaf N:P between 14 and 16 represent either $\mathrm{N}$ or P limitation or co-limitation. Another review of fertilization experiments made by Güsewell et al. (2004) concluded that $\mathrm{N}: \mathrm{P}<10$ indicated $\mathrm{N}$ limitation and $\mathrm{N}: \mathrm{P}>20$ indicated $\mathrm{P}$ limitation for most plant growth forms. Concentrations of $\mathrm{N}$ and $\mathrm{P}$ showed a strong positive correlation with each other in a variety of studies (Koerselman \& Meuleman, 1996; Thompson et al., 1997; Wu et al. 2012).

Little attention has been given to functional trait variation of TDF species growing along natural moisture and nutrient gradients, particularly among species native to the Caribbean. Hulshof \& Swenson (2010) quantified variation in leaf functional traits (LA, SLA, dry matter and water content) in ten co-existing tree species in a dry tropical forest in Costa Rica. However, the study was limited spatially and in the scope of environmental conditions, and the study left open the question of how TDF withinspecies level trait values would perform across a larger geographic scale or different environmental conditions. Renteria et al. (2005) and Renteria \& Jaramillo (2011) pursued those inquiries by performing leaf trait studies on deciduous species along a watershed topographic gradient, and across years with contrasting mean annual rainfall. Their study sites were located in sandy-clay-loam soils developed over rhyolite parent material in Mexico. In the 2005 study, species did not show differences in leaf $\mathrm{N}$ but LPC increased and N:P decreased with increasing moisture and nutrient availability. In 
the 2011 study they found a similar response to rainfall at the community level but not at the species level. Some species did not show variation in $\mathrm{N}$ or $\mathrm{P}$ for any of the 3 years. Chaturvedi (2011) showed intraspecific relative growth rate, SLA, leaf N, leaf P, and soil moisture content to be positively interrelated in a study of six TDF deciduous species in India. Only one of the species in the study cited above is semi-evergreen. None of these studies were located on soils developed over limestone parent material, or in the Insular Caribbean TDF.

Tropical dry forest tree species in Guanica, P.R. and Key Largo, FL have been reported to have high leaf nitrogen to phosphorus ratios at the community level $(\mathrm{N}: \mathrm{P}=56.6, \mathrm{~N}: \mathrm{P}=56.1$, respectively) and high $\mathrm{P}$ use efficiency ( $\mathrm{PUE}=6,057)$ therefore is believed to be highly efficient and limited in phosphorus (Murphy \& Lugo, 1986; Redwine, 2007). On the other hand, forest productivity generally increases with increasing water availability (Lugo et al. 1978), and the presence of a moisture gradient may confound analyses determined exclusively on nutrient availability (e.g., Renteria et al., 2005; Renteria \& Jaramillo, 2011). However, data describing co-variation of leaf traits and forest structure parameters at multiple sites along a rainfall gradient are scarce, particularly in the Insular Caribbean.

\subsection{Soil moisture, nutrient availability, and the soil-plant relationship}

Soil moisture has been shown to influence soil biological and chemical processes and consequently nutrient availability. Soils in sites with lower rainfall normally experience lower litter decomposition and nitrogen mineralization. Decomposition of litter showed a positive relationship with litter moisture content between $30-150 \%$ in a 
study by Haynes (1986). Nitrogen mineralization of organic matter has been shown to increase with increasing moisture up to field capacity (Stanford \& Epstein, 1974; Kladivko \& Keeney 1987). Struhar (2004) investigated the effects of different moisture regimes (wilting point, field capacity, flooded, air-dried, alternating wet and drying schedule) on $\mathrm{N}$ and $\mathrm{P}$ availability in mollisols developed on limestone substrate (Fluventic calciudolls; Coultas et al. 2008) under forest cover in Florida Everglades tree islands. Soil moisture treatments had a significant effect on available $\mathrm{N}$ but not on available P. Nitrate was found to be higher at field capacity or wilting point treatments than in the flooded or alternating wet/dry treatments.

Plant roots absorb N and P from the soil solution. Even though Struhar (2004) found no moisture effects on soil $\mathrm{P}$ availability, results from her pot study may not represent plant/soil nutrient dynamics under field conditions. In dry forest soils, short periods of $\mathrm{N}$ or $\mathrm{P}$ availability in the soil solution, caused by sporadic episodes of rainfall, are expected to aid plants in the uptake of $\mathrm{N}, \mathrm{P}$, and/or other nutrients. A neutral or slightly acidic $\mathrm{pH}$ of the soil solution is also expected to support the exchange of $\mathrm{P}$ from soil carbonate-bound forms on limestone areas.

Studies on soil fertilization and sites with natural contrasting fertility have demonstrated plant species in nutrient limited environments respond to increases in soil available nutrients by increasing leaf content of the limiting nutrient (Vitousek 1998; Wright et al. 2001; Wright et al. 2004). Nitrogen to phosphorus ratio have been suggested as indicators of the nature ( $\mathrm{N}$ or $\mathrm{P})$ of nutrient limitation a plant experiences, as discussed in Section 1.2 of this document (Koerselman \& Meuleman 1996; Tessier \& 
Raynal 2003). Since the TDF has been described as P limited ecosystem, an increase in soil P availability is expected to be reflected on species LPC.

\subsection{Statement of research}

In this study I quantified leaf functional traits [specific leaf area (SLA), leaf nitrogen content (LNC), leaf phosphorus content (LPC), and $\mathrm{N}: \mathrm{P}]$ in four co-existing tree species and characterized forest structure within six different rainfall regimes in south Florida and Puerto Rico to answer the following research questions:
A) How does rainfall affect intraspecific leaf traits (SLA, LNC, LPC, N:P)?
B) How does rainfall affect forest structural parameters?
C) To what extent do leaf characteristics and forest structure reflect soil nutrient concentrations in limestone areas?

\subsection{Hypothesis}

A) Intraspecific SLA, LNC, and LPC will increase along the increasing rainfall gradient. Leaf $\mathrm{N}: \mathrm{P}$ will decrease along the gradient.

B) Forest structure parameters (canopy height, basal area) will increase along the rainfall gradient and will exhibit a negative correlation with leaf $\mathrm{N}: \mathrm{P}$.

C) The leaf characteristics and forest structure parameter are responsive to variation in concentrations of soil $\mathrm{N}$ and $\mathrm{P}$.

\section{METHODS}

\subsection{Study sites}

This study uses the term ecological site (ecosite) as defined by USDA-NRCS (2014) for agriculture, range, and forest lands: "a distinctive kind of land with specific 
physical characteristics that differs from other kinds of land in its ability to produce a distinctive kind and amount of vegetation”.

A total of six ecosites, three each South Florida and Puerto Rico, with similar limestone parent material but contrasting rainfall regimes were identified in locations where TDF species occur. The six ecosites were classified by location and mean annual rainfall (i.e. 858, 1012, 1168, 1396, 1566 and $1933 \mathrm{~mm}$ per year), as PR-858, FL-1012, FL-1168, FL-1396, PR-1566, and PR-1933. Three separate stands were selected as study sites in each of the ecosites, for a total of nine sites per location (Puerto Rico and Florida) and 18 sites overall. All 18 sites have been forested for more than 60 years and lie within designated protected conservation areas. Twelve of the study sites are at the exact location of plots surveyed for related ecological research in the past (Ross et al. 1992; Murphy \& Lugo, 1986; Van Bloem et al. 2007).

The climate data used in this study is from the 1981-2010 Annual Climate Normals Data in the closest US National Weather Service weather station to each study site. All ecosites had a weather station located within a 10 mile radio except FL-1012 (29 mile) and FL-1167 (22 mile). Data were accessed through the United Stated National Oceanic and Atmospheric Administration National Climatic Data Center online records.

\section{- Puerto Rico}

The main island of the archipelago of Puerto Rico consist of about $27.5 \%$ limestone parent material. The limestone areas of the island are geographically subdivided into three: the southern karst, the northern karst, and dispersed karst area. The sites selected for this study are located on the southern (PR-858) and northern karst (PR-1566 \& PR-1933) areas (Figure 1). The southern limestone climate is drier and 
hotter than its counterpart in the north, because of a pronounced rain shadow occurring on the lee side of the central mountain range on the island.

The PR-858 sites are in the Guanica State Forest \& Biosphere Reserve, in the municipality of Guanica. The forest receives a mean annual rainfall of $858 \mathrm{~mm}$ and has a mean annual temperature of $26^{\circ} \mathrm{C}$. The sites are found over smooth limestone hill topography with an angle of inclination ranging from $0-15 \%$ (personal observation) and elevations ranging from 50 to $100 \mathrm{~m}$ above sea level. This ecosite includes a narrow list of approximately 33 tree species with diameters $\geq 2.5 \mathrm{~cm}$. The productivity of the forest is low with an annual fine litter production of $671 \mathrm{~g} / \mathrm{m}^{2}$. Forest structure has been described as having a short canopy of about $3-9 \mathrm{~m}$, basal area of $\sim 18-21 \mathrm{~m}^{2} / \mathrm{ha}$, and a stem density of 6,000-14,000 stems per hectare. ( $>2.5$ cm; Murphy \& Lugo, 1986; Van Bloem 2004; Medina et al. 2012)

The PR-1566 sites are located in the Cambalache State Forest Reserve in the municipality of Arecibo. The Cambalache Forest is in the northern limestone region, where it receives a mean annual rainfall of $1566 \mathrm{~mm}$ and has a mean annual temperature of $25.5^{\circ} \mathrm{C}$. The sites are found at the top of steep-sided karst hills $(30-50 \mathrm{~m}$ elevation) locally known as "mogotes". The environmental conditions at the top of mogotes recreate that of dry forest because of the little soil, high drainage and high wind; therefore, species characteristic of dry forest are usually found within a moist forest life zone. Forest structure has been described as having a canopy height of $9 \mathrm{~m}$, a basal area of about $36 \mathrm{~m}^{2} / \mathrm{ha}$, and a stem density of 418 per 0.1 ha. (Chinea 1980).

The PR-1933 study sites are located in the Guajataca State Forest Reserve in the municipality of Isabela. Mean annual rainfall is $1933 \mathrm{~mm}$ and mean temperature is 
$25.5{ }^{\circ} \mathrm{C}$. Similar to PR-1566 sites, PR-1933 is in the northern limestone region and are found at the top of the karst hills. Published information on the forest structure of this sites was not found.

\section{- Florida}

The FL-1012, FL-1168, and FL-1396 ecosites are located on limestone plateaus at the southern tip of the Florida peninsula. The ecosites surveyed in this study are climatically subdivided into: the lower Florida Keys, the upper Florida Keys, and the southern mainland (Figure 2). This area includes forested areas classified as sub-tropical TDF and locally known as tropical hardwood hammocks. Within the low elevation and topographic variation of the area, TDF occurs on rarely flooded and relatively higher elevations. An increasing rainfall gradient is reported from south to north in the region.

The FL-1012 represents the ecosite with the lowest rainfall level in FL. The sites surveyed here are located in: Sugar Loaf Key, Big Pine Key, and No Name Key. They occur where mean annual rainfall is $1012 \mathrm{~mm}$, mean annual temperature is $25.4^{\circ} \mathrm{C}$, topography is flat, and elevation is from $0.5-1.5 \mathrm{~m}$ above sea level. Similar to the driest site in Puerto Rico, the site includes a narrow list of $<40$ tree species with a DBH $\geq 2.5$ cm. Ecological sites classification in the FL Keys classified these stands as low productivity TDF with an annual fine litter production from 460 to $482 \mathrm{~g} / \mathrm{m}^{2}$. Forest structure features a short canopy of about $4-7 \mathrm{~m}$, basal area ranging from 15 to $29 \mathrm{~m}^{2} / \mathrm{ha}$, and a stem density of 222-244 stems per 0.1 hectare $(\geq 2.5 \mathrm{~cm}$ ) (Ross et al. 1992; Gillespie, 2005 \& 2006).

The FL-1168 sites are located in North Key Largo. The sites occur where mean annual rainfall is $1168 \mathrm{~mm}$; mean annual temperature is $25.1{ }^{\circ} \mathrm{C}$, topography is flat, and 
elevation is 1-4 meters above sea level. Tropical dry forest in Key Largo have the highest tropical woody $(\geq 2.5 \mathrm{~cm})$ species richness $(\sim 50)$ of all sites surveyed in FL. These stands are classified as high productivity hammock with an annual fine litter production from 603 to $620 \mathrm{~g} / \mathrm{m}^{2}$. Forest structure is characterized by canopies commonly $6-10 \mathrm{~m}$ in height, basal area of 24 to $46 \mathrm{~m}^{2} / \mathrm{ha}$, and stem density from 212 to 324 stems per 0.1 ha $(2.5 \geq \mathrm{cm})$ (Ross et al. 1992; Gillespie, 2006)

The FL-1396 sites are located on Long Pine Key, Everglades National Park, and known as Grimshawe, Mosier, and Royal Palm tree islands. They occur where mean annual rainfall is $1396 \mathrm{~mm}$, mean annual temperature is $24.0^{\circ} \mathrm{C}$, topography is flat, and elevation ranges from 2-4 $\mathrm{m}$ above sea level. The vegetation on these tree islands differ from the other selected study sites in Florida in that it features a higher presence of herbs, ferns, and epiphytes found anywhere from the ground to the upper canopy. The features are likely to be related to the high humidity of these locations. Forest structure has been described as a canopy height ranging from 7.4 to $8.7 \mathrm{~m}$ and a basal area of 24 to $28 \mathrm{~m}^{2} / \mathrm{ha}$ (Gillespie, 2006)

\subsection{Leaf sampling and analysis}

Four co-existing dry forest tree species, Bursera simaruba, Coccoloba diversifolia, Eugenia foetida and Metopium toxiferum, were subjects of this study. Leaves of three representative individuals of each species, randomly selected and more than 10 meters apart, were sampled in each of the 18 sites when available. Two of the species were not found in the following sites: E. foetida in the PR-1566, FL-1396 and 
PR-1933 sites; and M. toxiferum in PR-858, PR-1566 and PR-1933 sites. A total of 99 individual trees in FL and 59 in Puerto Rico were sampled.

Twenty canopy leaves were collected from 3 twigs on each individual. From this set, a subgroup of five non-senescent leaves were randomly selected for SLA analysis. A total of 790 leaves were analyzed for SLA by dividing leaf area by dry weight. Leaf area was calculated by digital scanning of leaves immediately after returning from the field and analyzing the image using ImageJ software (Version $1.47 \mathrm{v}$, National Institutes of Health, USA). Leaves were then transferred to a drying oven for a minimum of 72 hours at $65^{\circ} \mathrm{C}$, and weighed. The five leaves from each individual were then entirely ground to powder, sieved using a $0.65 \mathrm{~mm}$ lab grade sieve, and mixed to form a composite sample.

The composite sample from each individual tree was analyzed for leaf nitrogen content (LNC) and leaf phosphorus content (LPC). The LNC was determined using a $100 \mathrm{mg}$ subsample analyzed in a LECO True Spec CN element analyzer (LECO Consumables, St. Joseph, MI). The LPC was determined on duplicate 17-21 mg subsamples using the dry oxidation acid hydrolysis extraction procedure described in Solorzano and Sharp (1980) and performing a soluble reactive phosphorus (SRP) colorimetric analysis (EPA method 365.1) using a Thermo Scientific Spectronic 200 spectrophotometer.

\subsection{Soil sampling and analysis}

A trowel was used to collect three $500 \mathrm{~g}$ soil samples from the top $10 \mathrm{~cm}$ of soil at random locations in each of the 18 sites. A site average soil depth was calculated using 
five soil depth measurements done with a probe rod at random locations over $10 \mathrm{~m}$ apart in each site.

A total of 54 soil samples were analyzed for total nitrogen (TN), total phosphorus (TP), soluble reactive phosphorus (SRP), organic matter content (OMC), texture, and $\mathrm{pH}$. Total $\mathrm{N}$ and TP were determined using the same equipment and methods described above for leaf tissue analysis. Soil SRP was determined on $2.5 \mathrm{~g}$ subsamples processed using Olsen's sodium bicarbonate extraction method and colorimetric analysis (EPA method 365.1) on a Technicon Autoanalyzer II System (Pulse Instruments Ltd.). The OMC of soil was calculated from $4-5 \mathrm{~g}$ subsamples, using the loss on ignition (5 hours at $500^{\circ} \mathrm{C}$ ) method.

\subsection{Forest structure data collection}

Canopy height and basal area, two attributes of forest structure related to stand growth and wood volume, were measured. Canopy height, a measure of forest stature, is generally correlated with site productivity in stands of similar age and composition. Stand basal area is used to calculate the amount of wood in a stand; it is defined as the sum of the cross-sectional area, at $1.4 \mathrm{~m}$ height, of all stems for a given area. It is expressed in $\mathrm{m}^{2} /$ ha units.

A site mean canopy height and basal area was calculated from 10 measurements at random points, 10 meters apart, in each site. The canopy height was measured using an extendable height pole. The stand basal area was estimated using an angle gauge in a variable plot sampling method (Grosenbaugh, 1952). A basal area factor (BAF) of 10 
was selected. At each site, trees wider than the appropriate viewing window were counted from 10 points, and used as a multiplier of the BAF to estimate basal area.

\subsection{Statistical analysis}

Leaf trait analysis was performed individually for each species. The three individuals per species served as replicates from which a stand value for each trait in each species was calculated: SLA, LNC, LPC, and N:P. The stand value of each species leaf trait was then grouped and used to calculate an ecosite mean and standard deviation. A simple linear regression analysis was used to examine the effect of rainfall on leaf traits and forest structure parameters; relationships among traits; and leaf-soil relationships across the gradient. Analysis of variance and multiple comparison tests were performed to test for significant difference between ecosites or location (FL/PR) differences. Prior to these analyses, data were tested for normality and homogeneity of variance assumptions.

All analysis was performed in STATISTICA (Version 7.1, StatSoft Inc., Tulsa, OK, USA) and in Microsoft Excel (Version 97-2003; 2013). A p-value level $<0.05$ was used to determine statistical significance in all tests.

\section{RESULTS}

\subsection{Leaf traits (SLA, LNC, LPC, N:P)}

\section{- Evergreen species}

The four leaf traits measured in C. diversifolia and E. foetida, the two evergreen species, responded similarly along the rainfall gradient. Specific leaf area and LNC of these species increased with rainfall (Fig. $3 \& 4$ ). Furthermore, SLA was lowest for both 
species at the ecosites in the dry extreme of the rainfall gradient (PR-858 - FL-1012) and exhibited a positive shift at FL-1168. Coccoloba diversifolia SLA reached its highest value at PR-1566, while exhibiting little variation among all ecosites with a rainfall $\geq 1168 \mathrm{~mm}$. Eugenia foetida SLA presented its highest value at FL-1168, the highest rainfall level it was sampled. Coccoloba diversifolia and E. foetida LNC experienced a $70 \%$ increase towards the wet extreme of the rainfall gradient (Table 2).

Coccoloba diversifolia and E. foetida LPC failed to display a significant correlation with rainfall (Fig. 5). Coccoloba diversifolia exhibited its lowest value in FL1012 and its highest in FL-1396. The change in E. foetida LPC, from $0.72 \mathrm{mg} \mathrm{P} \mathrm{g}$ at the driest ecosite to $0.78 \mathrm{mg} \mathrm{P} \mathrm{g}$ at the most rainy, was not significant. Conversely, Coccoloba diversifolia and E. foetida leaf N:P (molar) increased from 24 and 28, respectively, to 44 at the wet extreme (Fig. 6).

Specific leaf area and LNC appeared to be closely linked to each other in positive correlations in C. diversifolia and E. foetida. The two traits, except C. Diversifolia SLA, also exhibited significant correlations with soil TN. Species LPC was not correlated with soil TP or SRP.

\section{- Drought-deciduous species}

Specific leaf area and LNC of the two deciduous species, B. simaruba and $M$. toxiferum, were not correlated with rainfall (Fig. 3\&4). The B. simaruba SLA / LNC multiple comparison test revealed an inter-state difference between individuals in FL and PR but no significant variation across the rainfall gradient within each location (FL/PR). 
Similarly, $M$. toxiferum did not presented significant variation in SLA or LNC across the rainfall gradient.

Bursera simaruba and M. toxiferum LPC was not correlated with rainfall. Bursera simaruba LPC was the lowest at FL-1168 and the highest at PR-858. Metopium toxiferum LPC showed little variation across the rainfall gradient with its lowest at FL1168 and its highest at FL-1396 (Fig. 5)

Figure 6 shows that, contrary to expectation, Bursera simaruba and M. toxiferum $\mathrm{N}: \mathrm{P}$ did not show a negative correlation with rainfall. Indeed, B. simaruba N:P showed a positive correlation with rainfall. Metopium toxiferum N:P did not exhibit a relationship with rainfall.

Bursera simaruba SLA exhibited a positive correlation with LNC, LPC and soil TN. B. simaruba and M. toxiferum LPC exhibited significant negative relationships with $\mathrm{N}: \mathrm{P}$.

\subsection{Forest structure}

\section{- Canopy height}

The forest canopy height for all study sites varied between 5.8 and $10.3 \mathrm{~m}$ and displayed an increase along the rainfall gradient (Fig. 7). Multiple comparison test reveal the canopy height was remarkably lower $(5.8 \mathrm{~m}-6.3 \mathrm{~m})$ in the two ecosites at the dry extreme of the gradient: PR-858 and FL-1012. Ecosites with rainfall $\geq 1168 \mathrm{~mm}$ exhibited little variation in canopy height (range 8.7-10.3 m). Canopy height exhibited significant positive relationships with evergreen species SLA and LNC.

\section{- Basal area}


The mean basal area for all ecosites varied between $15-32 \mathrm{~m}^{2} \mathrm{ha}^{-1}$ and increased along the rainfall gradient (Fig. 8). Similar to canopy height multiple comparison test results, significantly lower basal area values were found in the two ecosites at the dry extreme of the gradient: PR-858 and FL1012. Basal area exhibited significant positive relationships with evergreen species SLA and LNC.

\subsection{Soil properties and the relationships with leaf traits and structure}

\section{- Soil total nitrogen}

The mean soil TN for all sites ranged between $1.09 \pm 0.67 \%$ in PR-858 to $2.55 \pm$ $0.03 \%$ in FL-1168 (Fig. 9). No significant correlation was reported between soil TN and rainfall. Soil TN correlated with soil TP, soil SRP, and OMC.

Soil TN was the soil property that most strongly correlated with leaf traits. Evergreen species SLA, LNC and N:P increased with increasing soil $\mathrm{TN}$ (all $\mathrm{p} \leq 0.02$; except $C$. diversifolia SLA vs.TN: $\mathrm{p}=0.13$ ).

\section{- Soil total phosphorus}

The mean soil TP ranged from $162-1454 \mathrm{mg} \mathrm{P} \mathrm{kg}^{-1}$ (Fig. 10). No significant correlation was reported between soil TP and rainfall. Soil TP exhibited a strong relationship with soil TN, SRP, and OMC.

No strong relationships were found among leaf traits and soil TP. The strongest relationships were reported between E. foetida SLA and LPC and soil TP ( $\mathrm{p}=0.15$; $\mathrm{p}=0.17)$. B. simaruba SLA showed a weak negative relationship with $\mathrm{TP}(\mathrm{p}=0.12)$, while LPC did not show a relationship. Coccoloba diversifolia and M. toxiferum SLA, LPC, 
and N:P did not exhibit a relationship with site soil TP. E. foetida showed the highest correlation between species leaf $\mathrm{N}: \mathrm{P}$ and soil TP $(\mathrm{p}=0.12)$.

Basal area but not canopy height showed significant relationship with soil TP.

\section{- Soil soluble reactive phosphorus (SRP)}

The mean soil SRP ranged 13.6 - $49.2 \mathrm{mg}$ P kg (Fig. 11) and showed a positive relationship with soil TP.

The absolute value of soils SRP did not increased with rainfall; however, Figure 12 shows the percentage of SRP in TP increased with increasing rainfall.

No significant relationship was observed between species SLA, LPC and soil SRP.

\section{- Organic Matter Content (OMC)}

Table 1 shows the soil OMC was the lowest, 28\%, in PR-858 and ranged from 48 to $79 \%$ in all other study sites. Ecosites soil OMC showed a strong positive relationship with soil TN, TP, and SRP.

Evergreen species LNC and N:P showed a positive relationship with OMC (all $\mathrm{p} \leq$ 0.05 except E. foetida N:P: p=0.08). Eugenia foetida SLA showed a weak relationship with soil OMC $(\mathrm{p}=0.06)$. Bursera simaruba SLA, LNC, and LPC showed a negative relationship with OMC (all $\mathrm{p} \leq 0.05$ except LNC: $\mathrm{p}=0.06$ ).

\section{DISCUSSION}

\subsection{Evergreen species response to rainfall}

The data gathered for C. diversifolia and E. foetida SLA and LNC support the response predicted for these two traits in Hypothesis \#1: species SLA and LNC increased 
with rainfall across the study area (Fig. $3 \& 4$ ). The correlation between rainfall, SLA, and LNC confirmed that the general leaf morphological pattern documented by other researchers at the community and global level (Shields, 1950; Fonseca et al. 2000; Wright et al. 2004; Poorter, 2009) also occurred at the species-level in TDF evergreen species of the Caribbean. Working in Costa Rican TDF, Gotsch et al. (2010) found similar climatic effects on intraspecific variation in SLA and LNC in evergreen species.

The cause of the SLA/LNC pattern has been explained in terms of the "leaf economy" concept. The concept states that the production, functioning, and maintenance of plant structures have costs and benefits associated with them. Carbon and nutrients are fundamental constituents of plant biomass and the chemical substances (carbohydrates, ATP) fueling plant activity. Plants invest carbon and nutrients to produce leaf tissue and be able to assimilate carbon via photosynthesis. Thus, the benefit, or return, a plant gets from a leaf is in the amount of carbon fixed throughout the life of the leaf. Transpiration is an essential process for plants to fix carbon from the atmosphere and for plants to absorb/transport nutrients. The basic premise of the leaf economy theory is that plants inhabiting dry environments experience lower total transpiration and therefore have limited capability of assimilating the $\mathrm{C}, \mathrm{N}$, and $\mathrm{P}$ required for primary productivity rates. When the capability for transpiration/primary productivity is limited, plants are required to use carbon, nutrients, and water efficiently. Plants manage this by using strategies that help them decrease energy expenses in tissue construction, maximizing their net investment return, and/or producing leaves with features that help them conserve resources (Westoby et al. 2002; Poorter et al. 2009). 
The lower SLA shown by evergreen species in the driest sites may be an expression of a strategy to decrease energy expenses, maximize investment return, and conserve water. The fact SLA has shown a negative relationship with leaf-life span in multiple studies has led to the theory that investing in a leaf with lower SLA is a measure that maximizes investment return in the long-term. The thickness and lower surface area of a leaf with low SLA has also been suggested to make a plant more efficient in its use of water by reducing water loss via leaf area other than stomata. The low SLA feature is likely to aid the plant/leaf to resist wilting and thus mitigate cell damage. The fact that SLA (or its inverse: LMA) has been associated with rainfall, soil moisture, LNC, LPC, leaf life-span, growth, and soil $\mathrm{P}$ in a variety of studies provides a foundation for the generality of this theories. (Lambers \& Poorter, 1992; Cunningham et al. 1999; Wright 2001; Westoby et al. 2002; Wright et al. 2004; Redwine 2007; Gotsch 2010; Chaturvedi et al. 2011)

Coccoloba diversifolia and E. foetida LPC and N:P did not perform as expected in Hypothesis \#1. Species LPC neither increased along the increasing rainfall gradient (Fig. 5) nor was correlated with $\mathrm{LNC}$, as has been reported from analyses of community datasets (Gusewell 2004; Wright 2004). One paper that may shed light on how a TDF evergreen species performs under contrasting moisture regimes reported results that paralleled mine. Renteria et al. (2011) reported that through three years in which annual rainfall ranged by almost 3X, i.e., from 440 to $1,131 \mathrm{~mm}$, LPC of Piranhea mexicana remained constant. This result suggests TDF evergreen species employ a conservative/efficient use of phosphorus, which enables them to keep LPC stable. The conservative and efficient use of phosphorus may be mediated by high or adaptable levels 
of $\mathrm{P}$ resorption and high nutrient use efficiency as reported in forest nutrient dynamics studies in Florida Keys and Puerto Rico (Lugo \& Murphy 1986; Ross et al. 2003; Redwine 2007).

On the basis of the literature, an increase in evergreen species leaf N:P along the gradient was not expected (Renteria et al. 2005; Renteria \& Jaramillo, 2011; Gusewell, 2004). In the present study, the observed increase by C. diversifolia and E. foetida in leaf $\mathrm{N}: \mathrm{P}$ with rainfall (Fig. 6) was a function of a substantial increment in LNC and little variation in LPC. The molar N:P values of 24-28 shown at my driest site, PR-858, are indicative of nitrogen limitation; and differ from the phosphorus limitation suggested by community-level results from the same forest and month (July) in 1981 (Lugo, A.E. \& Murphy, P.G. 1986). In contrast, our C. diversifolia and E. foetida N:P values from Key Largo (FL-1168) are similar to those reported for different species by Redwine (2007) in the same location. They support the conclusion TDF in Key Largo is a phosphoruslimited system. The fact that LPC did not increase along the gradient but forest structure parameters, SLA, and LNC did, suggest that TDF evergreen study species growth is more limited by water and/or nitrogen than by phosphorus at the driest sites. In regards to this, it is important to note the reason for the incongruence of our evergreen species $\mathrm{N}: \mathrm{P}$ results with previous results from Guanica, PR may lie in the difference between research level, i.e. species-level vs. community-level. This result suggest TDF community-level traits do not always represent species-level traits. 


\subsection{Drought-deciduous species response to rainfall}

The data gathered for the drought-deciduous species, B. simaruba and $M$. toxiferum, SLA, LNC, LPC, N:P do not support hypothesis \#1: SLA, LNC, and LPC did not show an increasing trend, and N:P did not decrease, with increasing rainfall (Fig. 36). The lack of variation displayed by B. simaruba and M. toxiferum in SLA and LNC within Florida and Puerto Rico resembles results from drought-deciduous TDF species from the Pacific coast of Mexico. In that setting, none of the drought-deciduous study species exhibited a moisture effect on LMA or LNC in two studies that used topographic moisture gradient and 3 year mean annual rainfall data (Renteria et al. 2005; Renteria \& Jaramillo, 2011). Instead, their study species showed an increase in LPC and a decrease in N:P in response to higher moisture availability. The deciduous species in this study displayed the negative relationship between LPC and N:P (significant only for $B$. simaruba) but not in response to the rainfall gradient.

We attribute the observed insensitivity of drought-deciduous species to rainfall to their particular physiological and functional strategies, when compared to evergreens. Drought-deciduous species have evolved to be highly efficient in their water and nutrient

use. Three noteworthy strategies of drought-deciduous species are: dry season leaf abscission, highly productive leaves, and leaf nutrient resorption. Drought-deciduous species are known to shed their leaves and decline photosynthetic activity as a measure to conserve water when the resource is not available. They are said to compensate for the shorter leaf payback period by producing leaves with high SLA (low construction cost) and high LNC, which enables them to have higher photosynthetic capacity and make the most carbon assimilation out of the short period they retain functional capacity (Wright et 
al. 2004; Franco et al. 2005). The capacity to reabsorb nutrients from senescing leaves and adjust the total resorption in response to current soil moisture availability (Renteria et al. 2005; Renteria \& Jaramillo 2011) and other unidentified factors (Redwine, J. 2007) have also been documented. This features empower deciduous species with higher adaptability to short and long-term conditions and relaxes their relationship with rainfall and soil nutrients.

\subsection{Forest structure}

The hypothesis that forest structure parameters (canopy height, basal area) will increase along the rainfall gradient was supported. However, canopy height and basal area did not shift continuously through the gradient. Multiple comparison analysis suggests TDF structure can be grouped in two: sites with rainfall $\leq 1012$ and sites $\geq 1168$ mm. Plants, like other organisms, are known to have ecological niches. The realized niche is defined as the area/habitats where a plant is able to grow in the presence of the multiple limiting interactions it encounters in a natural setting. The realized niche can be understood as a continuum that has a peak (where the organism thrives) and factors limiting species success to both extremes. This study included sites scattered over most of the realized niche of TDF in Florida and Puerto Rico. At the dry extreme of the niche, Guanica, P.R., studies have demonstrated water is the main limiting factor affecting productivity (Lugo et al. 1978). The fact that the forest structure results did not hold a linear increase after reaching a peak on sites $\geq 1168 \mathrm{~mm}$ suggest water limits productivity in the driest sites $(\leq 1012)$ but organismal, biological and/or abiotic forces other than 
rainfall take over control of the canopy height and basal area of TDF on the wettest side of the gradient $(\geq 1168 \mathrm{~mm})$.

Leaf $\mathrm{N}: \mathrm{P}$ did not show the expected negative relationship with forest structure parameters. In contrast, leaf $\mathrm{N}: \mathrm{P}$ of three of the four study species increased and exhibited a positive correlation with forest structure parameters. The answer to the question of whether there is a relationship between a plant nutrient content and canopy height and basal area seems to be affirmative in regards to evergreen species nitrogen content, not to phosphorus content as expected.

\subsection{Soil properties and its effect on leaf traits}

The top $10 \mathrm{~cm}$ of soil in Florida and Puerto Rico TDF is characterized by high OMC (PR-858: 28\%, all other ecosites: 48-79 \% OMC), and high total $\mathrm{N}$ and $\mathrm{P}$. The positive relationship among $\mathrm{TN}, \mathrm{TP}$, and $\mathrm{SRP}$, and between these nutrients and $\mathrm{OMC}$ (Table 4), is typical in organic soils. Estimating available forms of nitrogen from TN data is not a standard practice; however, inferences can be done in organic soils. This inferences are based on studies that suggest (1) organic matter explains $78 \%$ of the variation in mineralizable $\mathrm{N}$ in a variety of soils in the Netherlands (Ros et al. 2011) and (2) decomposition of litter and $\mathrm{N}$ mineralization increase with increasing moisture (Stanford \& Epstein, 1974; Haynes 1986; Kladivko \& Keeney 1987).

Evergreen species LNC reflected soil TN levels (Fig. 13). Plants absorb nitrogen via uptake of inorganic forms, i.e. ammonium $\left(\mathrm{NH}_{4+}\right)$ and nitrate $\left(\mathrm{NO}_{3}\right)$, from soil. Ammonium and nitrates are made available by soil microbial activity and the process known as mineralization. Mineralization is the process by which microbes metabolize 
organic nitrogen and release inorganic forms of nitrogen to the soil. Major factors affecting nitrogen mineralization are: oxygen, temperature, amount of organic nitrogen, ratio of carbon to nitrogen $(\mathrm{C}: \mathrm{N})$, and moisture content. Oxygen and temperature are not factors inhibiting mineralization in this upland tropical forest. The high soil OMC and $\mathrm{TN}$, and its correlation, suggest the amount of organic nitrogen is high. A soil C:N ratio $<20$ is said to result in net mineralization. All our ecosites, except PR-858 (C:N=22), show soil $\mathrm{C}: \mathrm{N}$ ratio are adequate $(<20)$ for net mineralization. In ideal moisture conditions (15-70\%), the high quality of the soil and rapid OMC decomposition (44-65\% per 24 months) and turnover rates (Ross et al. 2003) would suggest inorganic forms of nitrogen to be available for plant uptake for the most part of the time. These facts, together with the positive relationships between evergreen species LNC and rainfall, suggest that even when soil TN showed a relationship with evergreen species LNC, soil moisture must be the main factor influencing mineralization and/or plant nitrogen uptake in TDF soils.

Soil P concentration is generally low relative to other plant macronutrients. Our TDF soils developed over limestone substrate showed high levels of TP, but only a small fraction (most ecosites $2-4 \%$, one 12\%) of this as soil SRP. Soil SRP values ranging from $13.6-49.2 \mathrm{mg} \mathrm{kg}$ are classified as low to medium in P fertility levels. Commercial soil test kits (LaMotte Co.) suggest $0-25 \mathrm{P} \mathrm{mg} \mathrm{kg}$ is low, 25-50 is medium, and +50 is high. General guidelines developed for soils in Hawaii suggest 25-35 P mg kg in heavy $\left(1.0 \mathrm{~g} \mathrm{~cm}^{3}\right)$ soils and 50-85 $\mathrm{P} \mathrm{mg} \mathrm{kg}$ in light $\left(0.5 \mathrm{~g} \mathrm{~cm}^{3}\right)$ soils are adequate for vegetable crops (Yost \& Uchida 2000). Soils in Guanica have reported $0.7-0.9 \mathrm{~g} \mathrm{~cm}^{3}$ and soils in the FL Keys $0.1-0.6 \mathrm{~g} \mathrm{~cm}^{3}$. The low availability of $\mathrm{P}$ has been associated to the low soil 
dissolution, high $\mathrm{pH}$ and high amount of calcium that binds to phosphate and creates insoluble forms of P (Lugo \& Murphy 1986). Our results support the hypothesis moisture increases dissolution and availability of $\mathrm{P}$ in limestone soils. The fraction of SRP to TP increased with increasing rainfall (Fig.12).

The fact that leaf traits did not reflect soil TP or SRP can be the result of two conditions: (1) TDF evergreen species employ a conservative/efficient use of phosphorus, which enables them to keep LPC stable and relaxes their relationship with soil P as discussed in Section 4.1 or (2) the variation in soil $\mathrm{P}$ is not enough to for the plant to exhibit them in LPC. The data for C. diversifolia LPC appears to suggest support for the first theory because of the independence of LPC from soil TP and SRP, in particular in PR-858. On the other hand, data gathered for E. foetida LPC suggest supports to the second theory (Fig. $14 \& 15)$.

The observed indications of nitrogen limitation in evergreen species at the driest sites may have been caused by a low LNC and/or may be a species level trait. Findings from the two evergreen study species do not challenge the current understanding that classifies TDF a phosphorus limited system at the community level. In the majority of our ecosites the species leaf N:P indicated a P limitation (Table 2\&3). In addition, results from our community-level forest structure and soil SRP analysis suggest a nutrientstructure relationship (Table 4).

\section{CONCLUSIONS AND IMPLICATIONS}

The tropical dry forest life zone has been classified as water-limited (Ewel \& Whitmore 1973; Lugo et al. 1978). Besides water availability and natural disturbances, 
TDF structure has been related to nutrient limitation. Community-level studies have concluded that TDF in Guanica, P.R. and Key Largo, FL are phosphorus-limited ecosystems (Lugo \& Murphy 1986; Redwine 2007). P limitation in these sites is attributed to the underlying limestone substrate, whose calcium content causes phosphorus to be in forms not available to plants; this limitation is exacerbated by the low moisture availability in the excessively drained substrate. Growth limitation may be further examined through the analysis of leaf functional traits, which provide insights into factors affecting TDF species growth in contrasting environments. To date little attention has been given to functional trait variation of TDF species growing along natural moisture and nutrient gradients, particularly among species native to the Caribbean. For that reason I designed a study that used a leaf functional trait approach to examine whether rainfall has a stress alleviation effect on TDF species and how this relates to the forest structure and soils properties.

The results of this study indicated clear differences between TDF evergreen and deciduous species leaf traits along the rainfall gradient. Leaf nitrogen content, SLA, and $\mathrm{N}: \mathrm{P}$ ratio of evergreen species, but not deciduous species, responded positively to increasing rainfall; leaf phosphorus content was unaffected in both groups. Canopy height and basal area reached maxima of $10.3 \mathrm{~m}$ and $31.4 \mathrm{~m}^{2} \mathrm{ha}^{-1}$, respectively, at 1168 $\mathrm{mm}$ annual rainfall. Evergreen species SLA and LNC and forest structure attributes exhibited similar patterns along the gradient: they increase at the dry extreme of the gradient, but exhibited little variation on ecosites with rainfall 1168-1933 mm. Leaf traits reflected soil properties only to a small extent. The answer to the question of whether there is a relationship between plant nutrient content and canopy height and basal area 
seems to be affirmative in regards to evergreen species leaf nitrogen content, not to a leaf phosphorus content as expected. This results led us to the conclusion that water is a major limiting factor in TDF and some species that comprise TDF ecosystems are limited by nitrogen in limestone sites with less than $\sim 1012 \mathrm{~mm}$ rainfall, but organismal, biological and/or abiotic forces other than rainfall control forest structure in moister sites.

The findings are relevant because they exemplify, and can potentially be used to predict, how Caribbean TDF forest structure would respond to long-term changes in rainfall as the ones forecasted as a cause of anthropogenic climate modification. On the basis of the evidence previously available, it was reasonable to suggest that an increase in rainfall and nutrient availability, at any level of the rainfall gradient, would result in a forest stand with structural attributes associated with greater productivity (i.e. greater canopy height and basal area); and consequently, a stand with different resources and ecological services, not only relevant to biodiversity but also to societal aspects. The present study reveals that only TDF stands in sites with a current annual rainfall regime under the $1012 \mathrm{~mm}$ would be expected to increase its height and basal area on the event of a long-term increase in rainfall. On the other hand, TDF structure in sites with a rainfall regime between $\sim 1168-1933 \mathrm{~mm}$ would not be expected to change in response to changes in rainfall unless it experiences levels below a threshold of $\sim 1168 \mathrm{~mm}$, case in which the structure attributes will be expected to decrease, or above the $\sim 1933 \mathrm{~mm}$, case in which the forest stand will start transitioning to a moist forest composition and structure.

Though our study focus was to examine how rainfall affects leaf traits and how they relate to forest structure and soil attributes in natural environments, I was surprised 
with the leaf phosphorus content findings because increasing rainfall did not resulted in higher LPC. The display of a larger forest structure without increases in LPC could strengthen the theory that TDF species are highly efficient in P (Lugo \& Murphy 1986; Redwine 2007) and promote the idea that species employ a conservative use of $\mathrm{P}$ even in environments with varying nutrient availability. The limited available information on TDF trait dynamics across variable moisture/nutrient treatments, particularly for evergreen species, limits generalization of the latter concept. Therefore, we call attention to the need for further research on the topic of TDF nutrient limitation.

\section{LITERATURE CITED}

Ackerly, D., Knight, C., Weiss, S., Barton, K., \& Starmer, K. (2002). Leaf size, specific leaf area and microhabitat distribution of chaparral woody plants: Contrasting patterns in species level and community level analyses. Oecologia, 130(3), 449-457.

doi:10.1007/s004420100805

Brown, S., \& Lugo, A. (1982). The storage and production of organic-matter in tropical forests and their role in the global carbon-cycle. Biotropica, 14(3), 161-187.

doi: $10.2307 / 2388024$

Ceccon, E., Huante, P., \& Rincon, E. (2006). Abiotic factors influencing tropical dry forests regeneration. Brazilian Archives of Biology and Technology, 49(2), 305-312.

Chaturvedi, R. K., Raghubanshi, A. S., \& Singh, J. S. (2011). Leaf attributes and tree growth in a tropical dry forest. Journal of Vegetation Science, 22(5), 917-931.

doi:10.1111/j.1654-1103.2011.01299.x 
Chaturvedi, R. K., Raghubanshi, A. S., \& Singh, J. S. (2011). Plant functional traits with particular reference to tropical deciduous forests: A review. Journal of Biosciences, 36(5), 963-981. doi:10.1007/s12038-011-9159-1

Coultas, C.L., Schwadron, M. Galbraith, JM. (2008). Petrocalcic horizon formation and prehistoric people's effect on Everglades tree island soils, Florida. Soil Survey Horizons $49,16-21$

Cunningham, S. A., Summerhayes, B., \& Westoby, M. (1999). Evolutionary divergences in leaf structure and chemistry, comparing rainfall and soil nutrient gradients. Ecological Monographs, 69(4), 569-588. doi:10.1890/0012-9615(1999)069[0569:EDILSA]2.0.CO;2

Díaz, S., \& Cabido, M. (2001). Vive la différence: Plant functional diversity matters to ecosystem processes. Trends in Ecology \& Evolution, 16(11), 646-655.

doi:http://dx.doi.org/10.1016/S0169-5347(01)02283-2

Ewel, J.J. \& Whitmore, J.L. (1973) The cological life zones of Puerto Rico and the U.S. Virgin Islands. ITF-18. United States Department of Agriculture, Forest Service, Institute of Tropical Forestry, Rio Piedras, Puerto Rico.

Fonseca, C., Overton, J., Collins, B., \& Westoby, M. (2000). Shifts in trait-combinations along rainfall and phosphorus gradients. Journal of Ecology, 88(6), 964-977. doi:10.1046/j.1365-2745.2000.00506.x

Gillespie, T. W., Zutta, B. R., Early, M. K., \& Saatchi, S. (2006). Predicting and quantifying the structure of tropical dry forests in south florida and the neotropics using spaceborne imagery. Global Ecology and Biogeography, 15(3), 225-236.

doi:10.1111/j.1466-8238.2005.00203.x

Gusewell, S. (2004). N : P ratios in terrestrial plants: Variation and functional significance. New Phytologist, 164(2), 243-266. doi:10.1111/j.1469-8137.2004.01192.x

Hoekstra, J. M., Boucher, T. M., Ricketts, T. H., \& Roberts, C. (2005). Confronting a biome crisis: Global disparities of habitat loss and protection. Ecology Letters, 8(1), 2329. doi:10.1111/j.1461-0248.2004.00686.x

Holdridge, L.R. (1967). Life zone ecology. Tropical Science Center, San Jose, Costa Rica Hulshof, C. M., \& Swenson, N. G. (2010). Variation in leaf functional trait values within and across individuals and species: An example from a costa rican dry forest. Functional Ecology, 24(1), 217-223. doi:10.1111/j.1365-2435.2009.01614.x 
Ingestad, T. (1979). Nitrogen stress in birch seedlings. Physiologia Plantarum, 45(1), 149-157. doi:10.1111/j.1399-3054.1979.tb01679.x

Janzen, D. H. (1988). Management of habitat fragments in a tropical dry forest: Growth. Annals of the Missouri Botanical Garden, 75(1), 105-116. doi:10.2307/2399468

Kearney, M., \& Porter, W. P. (2006). Ecologists have already started rebuilding community ecology from functional traits. Trends in Ecology \& Evolution, 21(9), 481482. doi:http://dx.doi.org/10.1016/j.tree.2006.06.019

Kladivko, E., \& Keeney, D. (1987). Soil nitrogen mineralization as affected by water and temperature interactions. Biology and Fertility of Soils, 5(3), 248-252.

doi:10.1007/BF00256909

Lajtha, K., \& Klein, M. (1988). The effect of varying nitrogen and phosphorus availability on nutrient use by larrea tridentata, a desert evergreen shrub. Oecologia, 75(3), 348-353. doi:10.1007/BF00376936

Lambers, H., \& Poorter, H. (1992). Inherent variation in growth rate between higher plants: A search for physiological causes and ecological consequences. Advances in Ecological Research, 23(0), 187-261. doi:http://dx.doi.org/10.1016/S00652504(08)60148-8

Lambrecht, S. C., \& Dawson, T. E. (2007). Correlated variation of floral and leaf traits along a moisture availability gradient. Oecologia, 151(4), 574-583. doi:10.1007/s00442006-0617-7

Lugo, A.E. (1978). Structure, productivity, and transpiration of a subtropical dry forest in Puerto Rico. Biotropica. 10(4), 278-291

Lugo, A. E., \& Murphy, P. G. (1986). Nutrient dynamics of a puerto rican subtropical dry forest. Journal of Tropical Ecology, 2(01), 55. doi:10.1017/S0266467400000602

McDonald, P., Fonseca, C., Overton, J., \& Westoby, M. (2003). Leaf-size divergence along rainfall and soil-nutrient gradients: Is the method of size reduction common among clades? Functional Ecology, 17(1), 50-57. doi:10.1046/j.1365-2435.2003.00698.x

McGill, B. J., Enquist, B. J., Weiher, E., \& Westoby, M. (2006). Rebuilding community ecology from functional traits. Trends in Ecology \& Evolution, 21(4), 178-185. doi:http://dx.doi.org/10.1016/j.tree.2006.02.002 
Medina, E., Garcia, V., \& Cuevas, E. (1990). Sclerophylly and oligotrophic environments: Relationships between leaf structure, mineral nutrient content, and drought resistance in tropical rain forests of the upper rio negro region. Biotropica, 22(1), 51-64.

Medina, E.; Cuevas, E.; Molina, S.; Lugo, A.E.; Ramos, O. (2012). Structural variability and species diversity of a dwarf Caribbean dry forest. Caribbean Journal of Science 4(23):203-215.

Murphy, P. G., Lugo, A. E., Murphy, A. J., \& Nepstad, D. C. (1995). The dry forest of Puerto Rico's south coast. In Lugo, A.E. \& Lowe, C. (Ed.) Tropical forests : management and ecology; Ecological studies ; vol. 112 ed., pp. 178-209). New York, USA: SpringerVerlag. doi:038794320X

Poorter, H., Niinemets, U., Poorter, L., Wright, I. J., \& Villar, R. (2009). Causes and consequences of variation in leaf mass per area (LMA): A meta-analysis (vol 182, pg 565, 2009). New Phytologist, 183(4), 1222-1222.

Portillo-Quintero, C. A., \& Sanchez-Azofeifa, G. A. (2010). Extent and conservation of tropical dry forests in the americas. Biological Conservation, 143(1), 144-155.

doi:10.1016/j.biocon.2009.09.020

Redwine, J. R. (2007). Leaf morphology scales multi-annual trends in nutrient cycling and leaf, flower, and fruiting phenology among species in the sub-tropical hardwood forests of the northern florida keys. Florida International University. Dissertation.

Reich, P. B., Walters, M. B., \& Ellsworth, D. S. (1997). From tropics to tundra: Global convergence in plant functioning. Proceedings of the National Academy of Sciences of the United States of America, 94, 13730-13734. doi:10.1073/pnas.94.25.13730

Renteria, L., Jaramillo, V., Martinez-Yrizar, A., \& Perez-Jimenez, A. (2005). Nitrogen and phosphorus resorption in trees of a mexican tropical dry forest. Trees-Structure and Function, 19(4), 431-441. doi:10.1007/s00468-004-0402-3

Renteria, L. Y., \& Jaramillo, V. J. (2011). Rainfall drives leaf traits and leaf nutrient resorption in a tropical dry forest in mexico. Oecologia, 165(1), 201-211. doi:10.1007/s00442-010-1704-3

Ros, G. H., Hanegraaf, M. C., Hoffland, E., \& van Riemsdijk, W. H. (2011). Predicting soil N mineralization: Relevance of organic matter fractions and soil properties. Soil Biology and Biochemistry, 43(8), 1714-1722.

doi:http://dx.doi.org/10.1016/j.soilbio.2011.04.017 
Ross, M. S., Mitchell-Bruker, S., Sah, J. P., Stothoff, S., Ruiz, P. L., Reed, D. L., . . Coultas, C. L. (2006). Interaction of hydrology and nutrient limitation in the ridge and slough landscape of the southern everglades. Hydrobiologia, 569, 37-59.

doi:10.1007/s10750-006-0121-4

Ross, M., Obrien, J., \& Flynn, L. (1992). Ecological site classification of florida keys terrestrial habitats. Biotropica, 24(4), 488-502. doi:10.2307/2389011

Sanchez-Azofeifa, G., Quesada, M., Rodriguez, J., Nassar, J., Stoner, K., Castillo, A., . . . Cuevas-Reyes, P. (2005). Research priorities for neotropical dry forests. Biotropica, 37(4), 477-485. doi:10.1111/j.1744-7429.2005.00066.x

Stanford, G. \& Epstein, E. (1974.). Nitrogen mineralization-water relations in soils.(38), 103-107. doi:10.2136/sssaj1974.03615995003800010032x

Struhar, M. E. (2004). Relationship between soil moisture and nutrient availability in tree islands of shark slough, everglades national park. Florida International University.

Masters Thesis.

Tessier, J. T., \& Raynal, D. J. (2003). Use of nitrogen to phosphorus ratios in plant tissue as an indicator of nutrient limitation and nitrogen saturation. Journal of Applied Ecology, 40(3), 523-534. doi:10.1046/j.1365-2664.2003.00820.x

Thompson, K., Parkinson, J., Band, S., \& Spencer, R. (1997). A comparative study of leaf nutrient concentrations in a regional herbaceous flora. New Phytologist, 136(4), 679689. doi:10.1046/j.1469-8137.1997.00787.x

United States Department of Agriculture, Natural Resources Conservation Service (2014) National Ecological Site Handbook. 1st edition.

Van Bloem, S., Lugo, A., \& Murphy, P. (2006). Structural response of caribbean dry forests to hurricane winds: A case study from guanica forest, puerto rico. Journal of Biogeography, 33(3), 517-523. doi:10.1111/j.1365-2699.2005.01450.x

Van Bloem, S. J., Murphy, P. G., \& Lugo, A. E. (2007). A link between hurricaneinduced tree sprouting, high stem density and short canopy in tropical dry forest. Tree Physiology, 27(3), 475-480.

Van Bloem, S. J., Murphy, P. G., \& Lugo, A. E. (2007). A link between hurricaneinduced tree sprouting, high stem density and short canopy in tropical dry forest. Tree Physiology, 27(3), 475-480. 
Van, d. D. (1974). Prediction of mineral nutrient status of trees by foliar analysis. The Botanical Review, 40(3), 347-394. doi:10.1007/BF02860066

Vieira, D., \& Scariot, A. (2006). Principles of natural regeneration of tropical dry forests for restoration. Restoration Ecology, 14(1), 11-20. doi:10.1111/j.1526-

100X.2006.00100.x

Westoby. (2002). Plant ecological strategies: Some leading dimensions of variation between species. Annual Review of Ecology and Systematics, 33, 125; 125-159; 159.

Westoby, M., \& Wright, I. J. (2006). Land-plant ecology on the basis of functional traits. Trends in Ecology \& Evolution, 21(5), 261-268.

doi:http://dx.doi.org/10.1016/j.tree.2006.02.004

Wright, I. J., Reich, P. B., \& Westoby, M. (2004). The worldwide leaf economics spectrum. Nature, 428, 821-827. doi:10.1038/nature02403

Wright, I. J., Westoby, M., \& Reich, P. B. (2002). Convergence towards higher leaf mass per area in dry and nutrient-poor habitats has different consequences for leaf life span. Journal of Ecology, 90(3), 534-543. doi:10.1046/j.1365-2745.2002.00689

J. A. Silva and Uchida, R. (2000) Interpreting Soil Nutrient Analysis Data In Plant Nutrient Management in Hawaii's Soils, Approaches for Tropical and Subtropical Agriculture. J. A. Silva and R. Uchida (Ed.) College of Tropical Agriculture and Human Resources, University of Hawaii at Manoa 
Table 1. Summary of ecological data collected in study sites

\begin{tabular}{|c|c|c|c|c|c|c|c|c|}
\hline $\begin{array}{c}\text { Ecosite } \\
\text { Rainfall } \\
(\mathrm{mm})\end{array}$ & $\begin{array}{l}\text { Study Sites } \\
\text { Location }\end{array}$ & $\begin{array}{l}\text { Elevation } \\
\text { (m) }\end{array}$ & $\begin{array}{l}\text { Canopy } \\
\text { Height } \\
\text { (m) }\end{array}$ & $\begin{array}{c}\text { Basal area } \\
\left(\mathrm{m}^{2} / \mathrm{ha}\right)\end{array}$ & $\begin{array}{c}\text { Soil TN } \\
(\%)\end{array}$ & $\begin{array}{l}\text { Soil TP } \\
\left(\mathrm{mg} \mathrm{kg}^{-1}\right)\end{array}$ & $\begin{array}{l}\text { Soil SRP } \\
\left(\mathrm{mg} \mathrm{kg}^{-1}\right)\end{array}$ & $\begin{array}{l}\text { Soil } \\
\text { OMC } \\
\text { (\%) }\end{array}$ \\
\hline 858 & $\begin{array}{c}\text { Guanica State } \\
\text { Forest, P.R. }\end{array}$ & $181-210$ & 6.3 & 18.2 & 1.09 & 530.32 & 13.60 & 28 \\
\hline 1012 & $\begin{array}{l}\text { Lower Keys } \\
\text { Hammocks, FL }\end{array}$ & $0.3-3$ & 5.8 & 14.8 & 2.22 & 1052.87 & 29.42 & 76 \\
\hline 1168 & $\begin{array}{c}\text { Key Largo } \\
\text { Hammocks, FL }\end{array}$ & $0.5-4$ & 10.3 & 31.5 & 2.91 & 1454.23 & 49.17 & 79 \\
\hline 1396 & $\begin{array}{c}\text { Long Pine Key, } \\
\text { Everglades } \\
\text { National Park, FL }\end{array}$ & $0.5-4$ & 8.7 & 27.8 & 2.55 & 1169.12 & 43.26 & 51 \\
\hline 1566 & $\begin{array}{c}\text { Mogotes, } \\
\text { Cambalache } \\
\text { State Forest, P.R. }\end{array}$ & $59-154$ & 8.8 & 24.3 & 2.13 & 802.28 & 28.53 & 57 \\
\hline 1933 & $\begin{array}{c}\text { Mogotes, } \\
\text { Guajataca State } \\
\text { Forest, PR }\end{array}$ & $236-312$ & 10.2 & 22.6 & 1.49 & 161.87 & 14.78 & 48 \\
\hline
\end{tabular}


Table 2. Summary of evergreen species leaf functional traits [Specific leaf area (SLA), Leaf nitrogen content (LNC), Leaf phosphorus content (LPC), and nitrogen to phosphorus molar ratio (N:P)] for study species in ecosites. Values are means. \pm 1 standard error in parenthesis.

\begin{tabular}{|c|c|c|c|c|}
\hline $\begin{array}{l}\text { LOCATION I } \\
\text { RAINFALL }\end{array}$ & SLA (mm2/mg) & LNC (mg/g) & $P(\mathrm{mg} / \mathrm{g})$ & $\mathrm{N}: \mathrm{P}$ ratio (molar) \\
\hline \multicolumn{5}{|c|}{ Coccoloba diversifolia } \\
\hline PR-858 & $7.30(0.25)$ & $10.05(0.38)$ & $0.90(0.03)$ & $24.7(0.2)$ \\
\hline FL-1012 & $7.43(0.14)$ & $14.53(0.32)$ & $0.78(0.02)$ & $41.00(1.3)$ \\
\hline FL-1168 & $8.74(0.12)$ & $15.33(0.71)$ & $0.81(0.02)$ & $42.3(1.8)$ \\
\hline FL-1396 & $8.52(0.06)$ & $17.86(0.88)$ & $1.01(0.10)$ & $40.3(5.8)$ \\
\hline PR-1566 & $9.12(0.49)$ & $16.24(1.00)$ & $0.86(0.04)$ & $41.7(2.7)$ \\
\hline PR-1933 & $8.92(0.42)$ & $16.49(0.25)$ & $0.85(0.00)$ & $43.1(0.5)$ \\
\hline \multicolumn{5}{|l|}{ Eugenia foetida } \\
\hline PR-858 & $6.51(0.16)$ & $9.03(0.27)$ & $0.72(0.01)$ & $28.1(1.2)$ \\
\hline FL-1012 & $7.06(0.84)$ & $9.91(1.62)$ & $0.75(0.09)$ & $29.2(2.0)$ \\
\hline FL-1168 & $10.33(0.41)$ & $15.37(1.33)$ & $0.78(0.07)$ & $44.3(2.5)$ \\
\hline
\end{tabular}


Table 3. Summary of deciduous species leaf functional traits [specific leaf area (SLA), leaf nitrogen content (LNC), leaf phosphorus content (LPC), and nitrogen to phosphorus molar ratio (N:P)] for study species in ecosites. Values are means. \pm 1 standard error in parenthesis.

\begin{tabular}{|c|c|c|c|c|}
\hline $\begin{array}{c}\text { LOCATION } \\
\text { RAINFALL }\end{array}$ & SLA (mm2/mg) & LNC (mg/g) & P (mg/g) & N:P ratio (molar) \\
\hline Bursera simaruba & \multicolumn{5}{|l|}{} & \\
\hline PR-858 & $15.14(0.77)$ & $17.38(0.50)$ & $1.24(0.08)$ & $31.1(1.2)$ \\
\hline FL-1012 & $8.81(0.42)$ & $13.66(0.49)$ & $0.75(0.04)$ & $38.4(2.5)$ \\
\hline FL-1168 & $10.41(0.73)$ & $15.44(0.57)$ & $0.89(0.03)$ & $38.7(2.3)$ \\
\hline FL-1396 & $10.35(0.51)$ & $15.61(1.67)$ & $1.03(0.09)$ & $34.0(2.7)$ \\
\hline PR-1566 & $13.45(1.19)$ & $19.85(1.05)$ & $1.19(0.09)$ & $37.1(2.3)$ \\
\hline PR-1933 & $12.70(0.94)$ & $17.41(0.85)$ & $0.87(0.03)$ & $44.4(0.9)$ \\
\hline Metopium toxiferum & & & & $41.5(3.0)$ \\
\hline FL-1012 & $7.36(0.53)$ & $12.40(1.17)$ & $0.66(0.02)$ & $46.8(1.1)$ \\
\hline FL-1168 & $8.18(0.46)$ & $13.08(0.44)$ & $0.62(0.02)$ & $40.7(2.6)$ \\
\hline FL-1396 & $8.03(0.30)$ & $12.49(0.32)$ & $0.68(0.03)$ & \\
\hline
\end{tabular}


Table 4. Correlations between soil and forest structure variables

\begin{tabular}{|c|c|c|c|c|}
\hline & Soil TN (\%) & $\begin{array}{c}\text { Soil } \\
\mathrm{TP}(\mathrm{mg} / \mathrm{kg})\end{array}$ & $\begin{array}{l}\text { Soil SRP } \\
\text { (mg/kg) }\end{array}$ & $\begin{array}{c}\text { Soil OMC } \\
(\%)\end{array}$ \\
\hline $\begin{array}{c}\text { Canopy } \\
\text { Height (m) }\end{array}$ & $\begin{array}{l}r^{2}=0.22 \\
p=0.00\end{array}$ & $\begin{array}{l}r^{2}=0.03 \\
p=0.19\end{array}$ & $\begin{array}{l}r^{2}=0.19 \\
p=0.00\end{array}$ & $\begin{array}{l}r^{2}=0.05 \\
p=0.10\end{array}$ \\
\hline Basal area & $\begin{array}{l}r^{2}=0.36 \\
p=0.00\end{array}$ & $\begin{array}{l}r^{2}=0.14 \\
p=0.01\end{array}$ & $\begin{array}{l}r^{2}=0.36 \\
p=0.00\end{array}$ & $\begin{array}{l}r^{2}=0.05 \\
p=0.12\end{array}$ \\
\hline Soil TN (\%) & & $\begin{array}{l}r^{2}=0.41 \\
p=0.00\end{array}$ & $\begin{array}{l}r^{2}=0.62 \\
p=0.00\end{array}$ & $\begin{array}{l}r^{2}=0.65 \\
p=0.00\end{array}$ \\
\hline $\begin{array}{c}\text { Soil } \\
\text { TP(mg/kg) }\end{array}$ & & & $\begin{array}{l}r^{2}=0.76 \\
p=0.00\end{array}$ & $\begin{array}{l}r^{2}=0.24 \\
p=0.04\end{array}$ \\
\hline $\begin{array}{l}\text { Soil SRP } \\
\text { (mg/kg) }\end{array}$ & & & & $\begin{array}{l}r^{2}=0.37 \\
p=0.01\end{array}$ \\
\hline
\end{tabular}




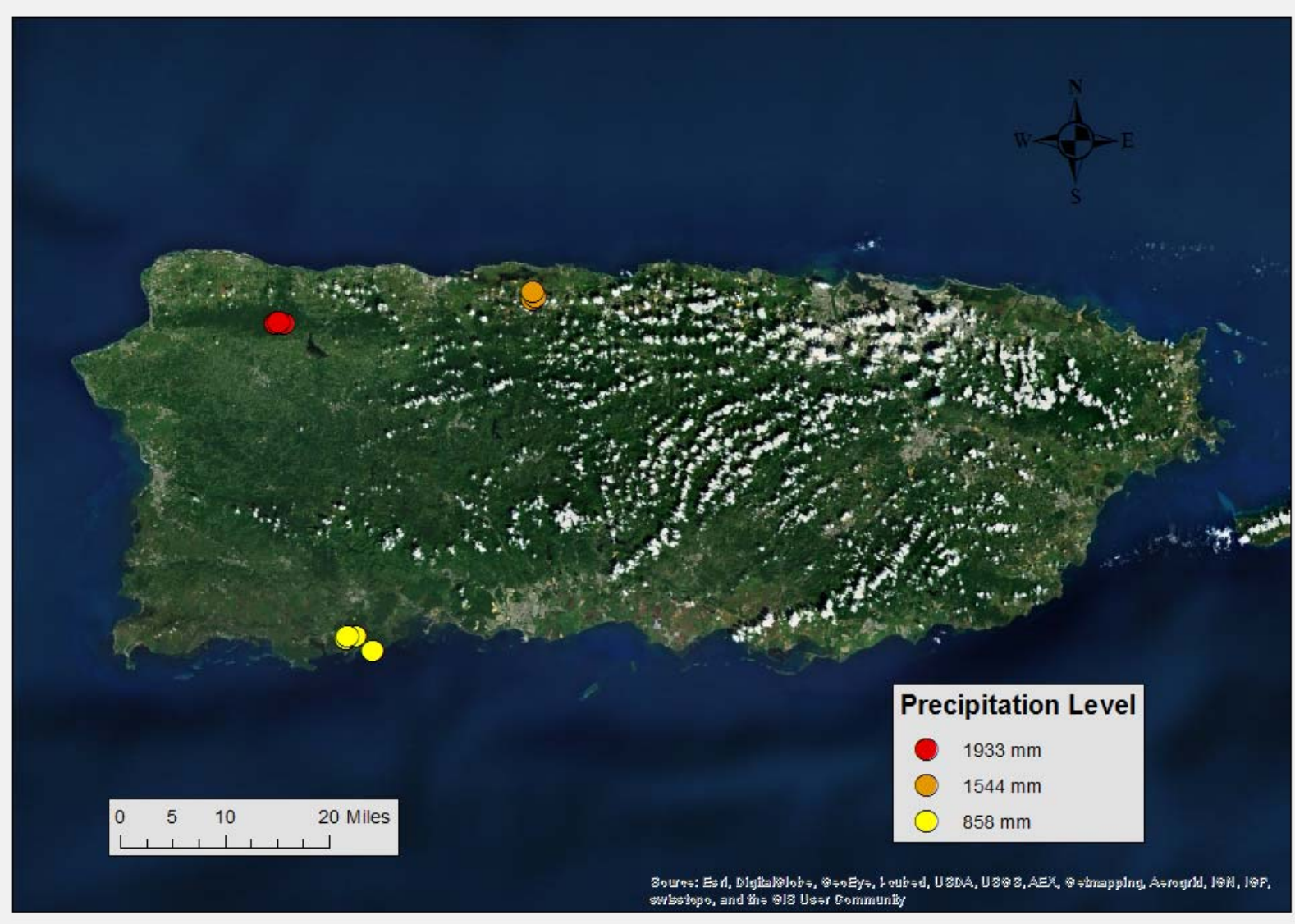

Figure 1. Map showing the location of Puerto Rico study sites 


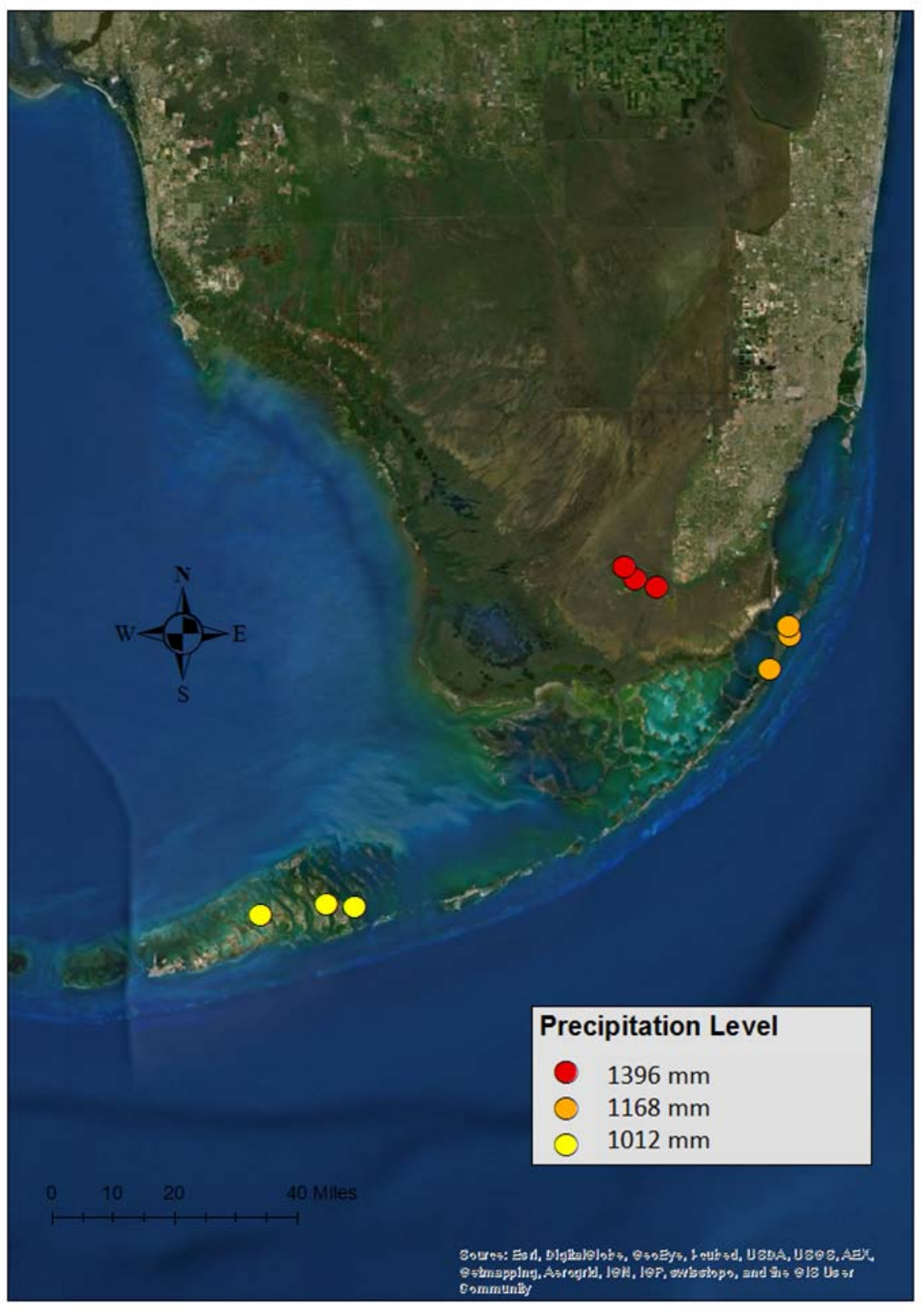

Figure 2. Map showing the location of Florida study sites 


\section{MEAN ANNUAL RAINFALL VS. SPECIFIC LEAF AREA}

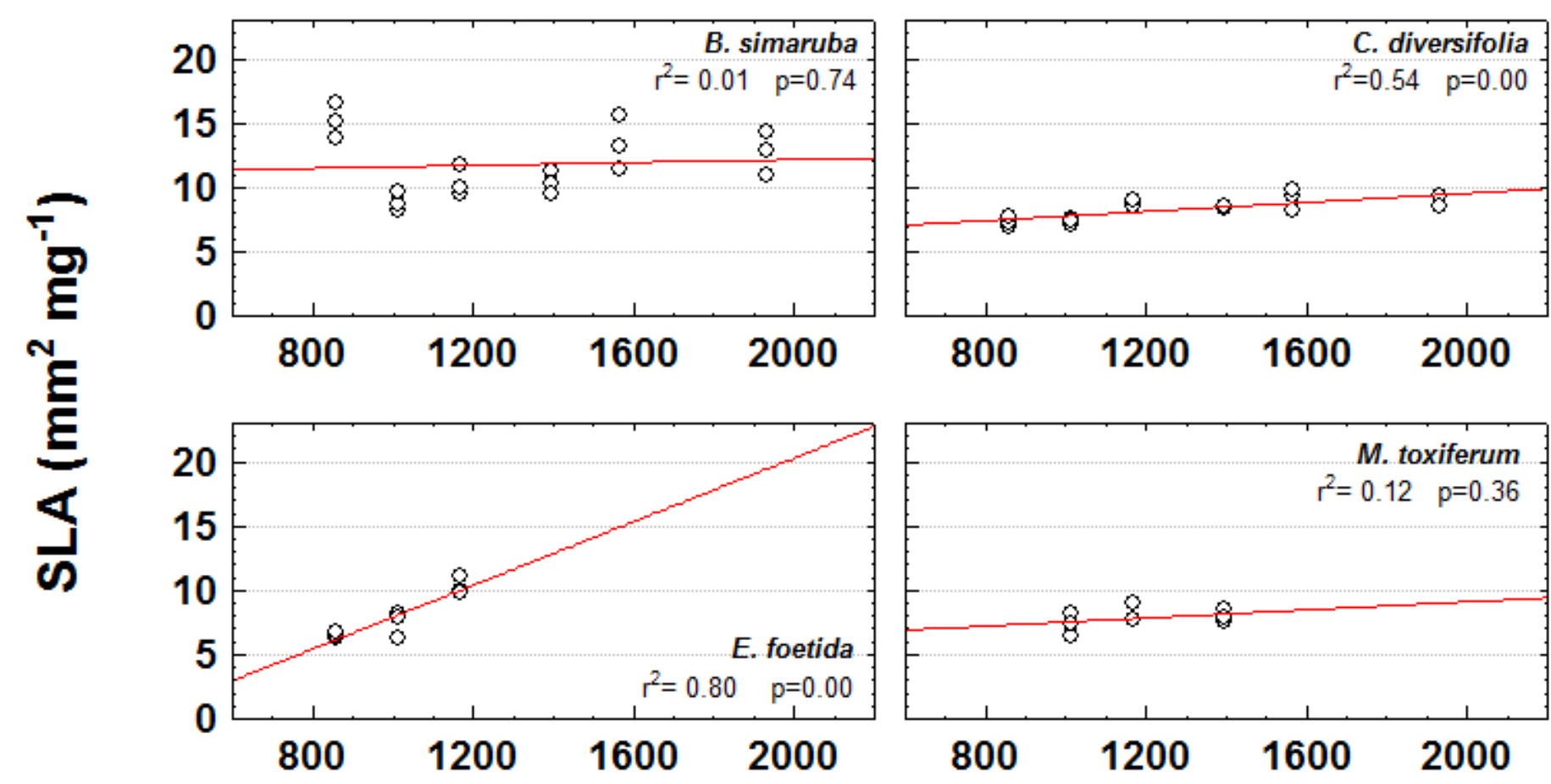

MEAN ANNUAL RAINFALL (mm)

Figure 3. Scatterplot showing the effect of rainfall on specific leaf area of study species 


\section{MEAN ANNUAL RAINFALL VS. LEAF NITROGEN CONTENT}

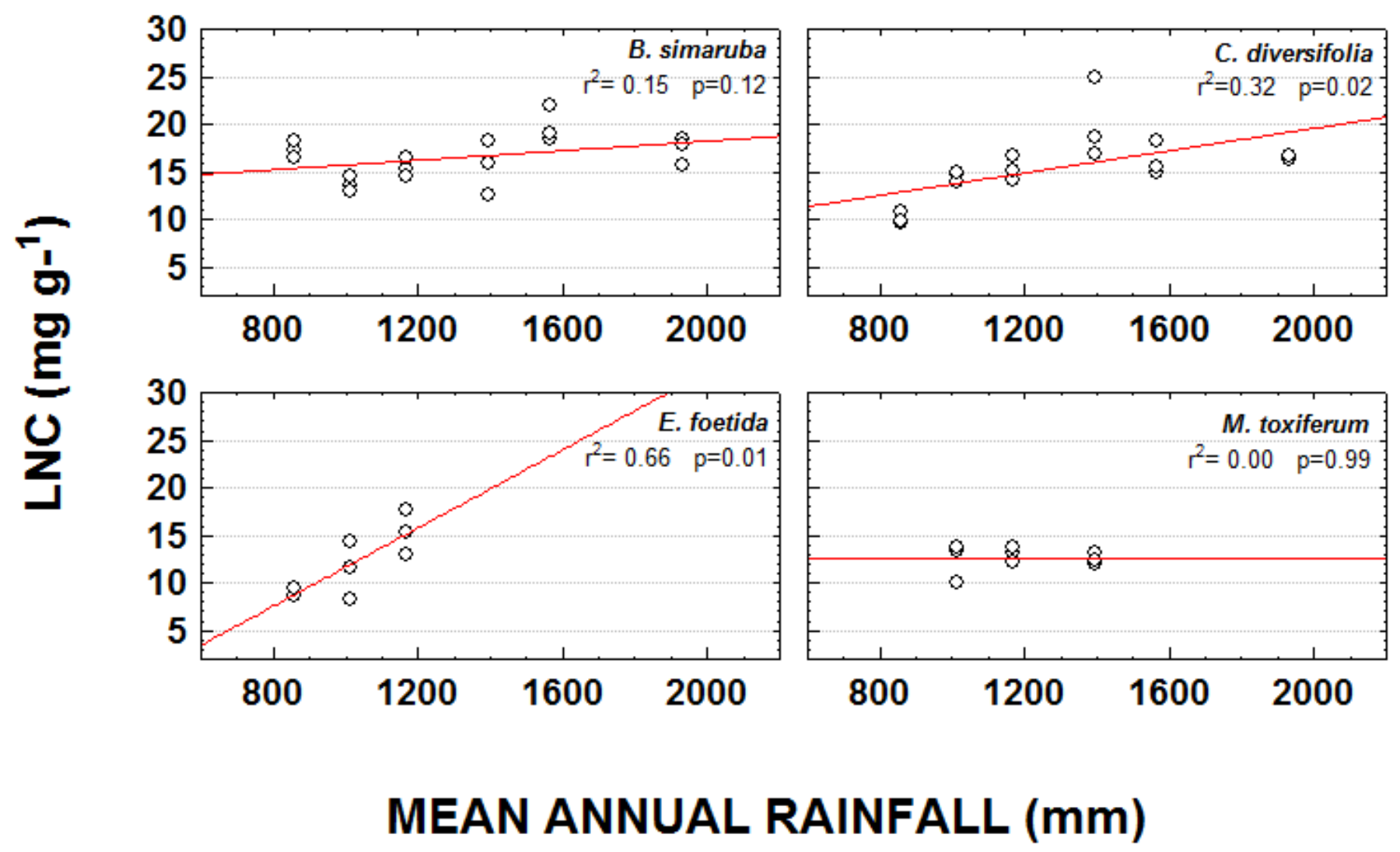

Figure 4. Scatterplot showing the effect of rainfall on leaf nitrogen content of study species 
MEAN ANNUAL RAINFALL VS. LEAF PHOSPHORUS CONTENT

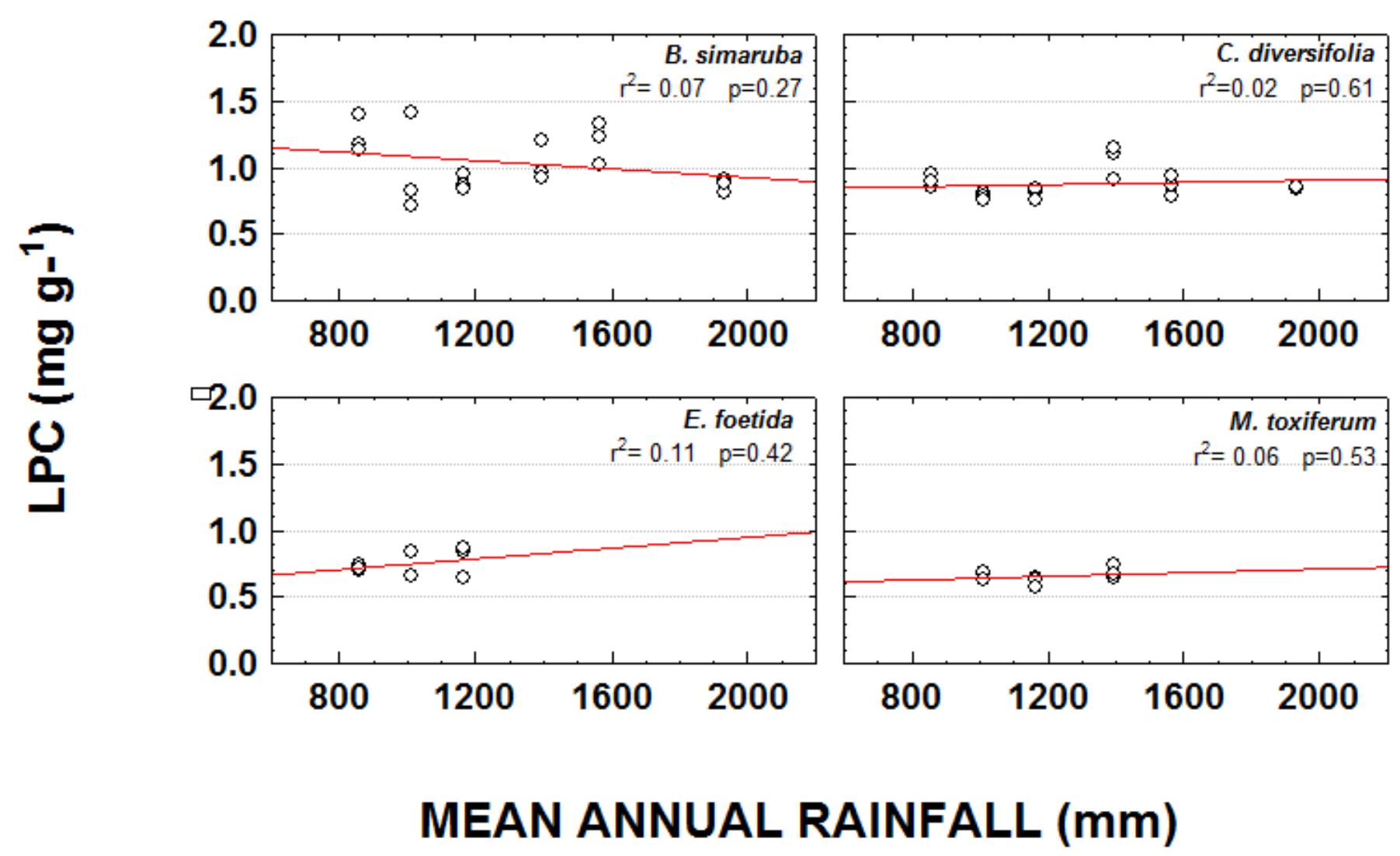

Figure 5. Scatterplot showing the effect of rainfall on leaf phosphorus content of study species 


\section{MEAN ANNUAL RAINFALL VS. LEAF N:P RATIO}

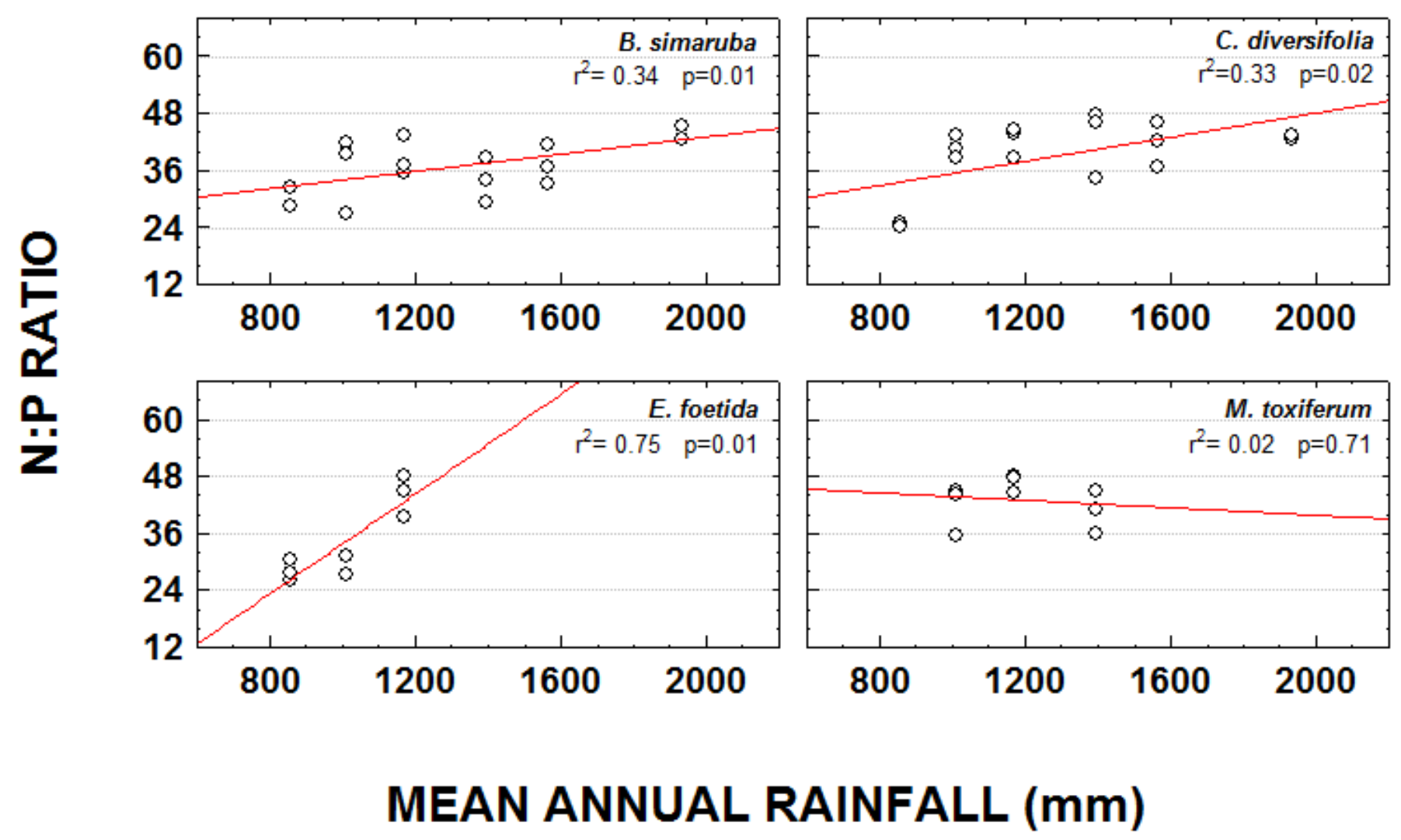

Figure 6. Scatterplot showing the effect of rainfall on leaf N:P molar ratio of study species 


\section{MEAN ANNUAL RAINFALL VS. CANOPY HEIGHT}

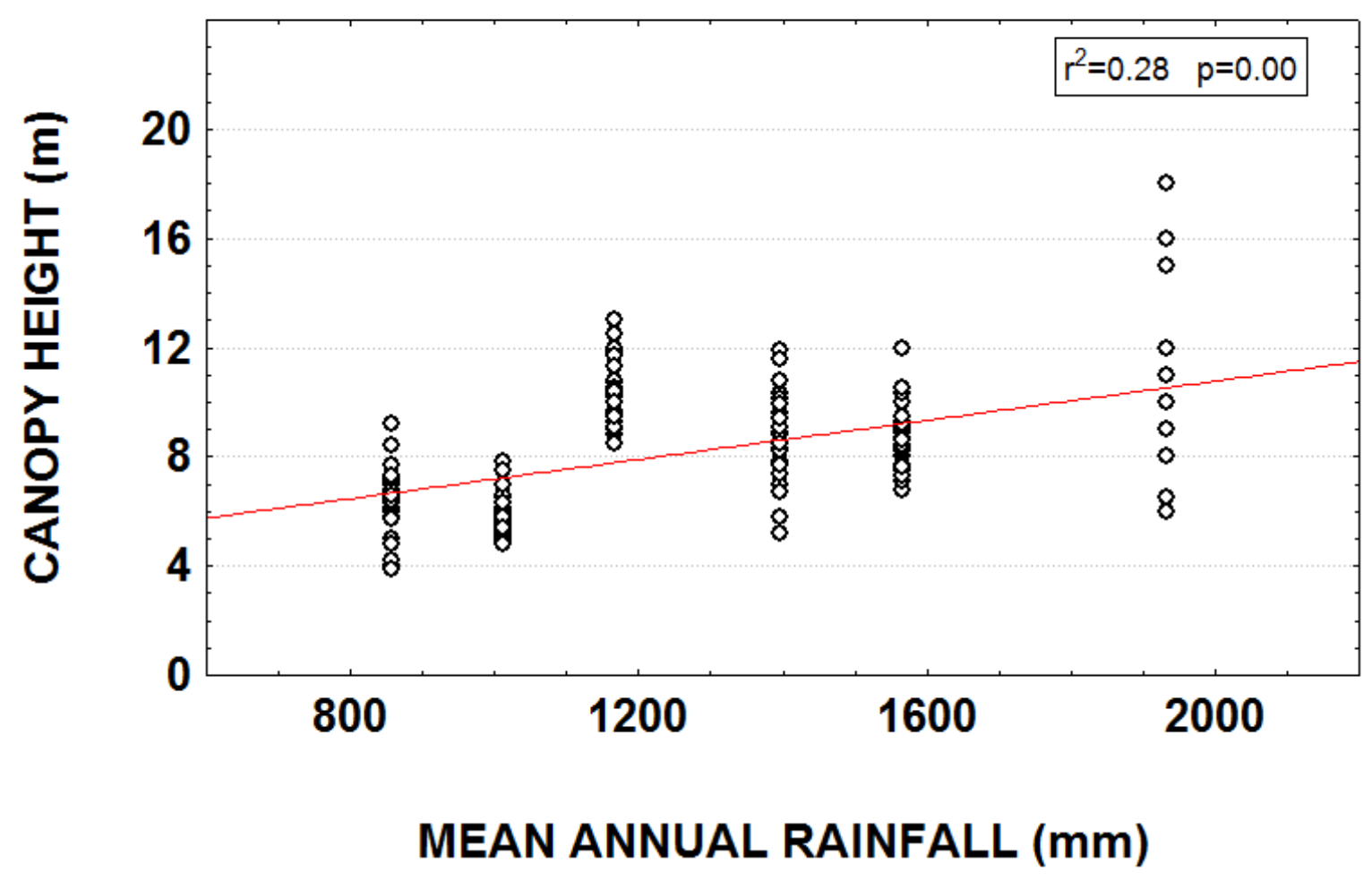

Figure 7. Scatterplot showing the effect of rainfall on canopy height 
MEAN ANNUAL RAINFALL VS. BASAL AREA

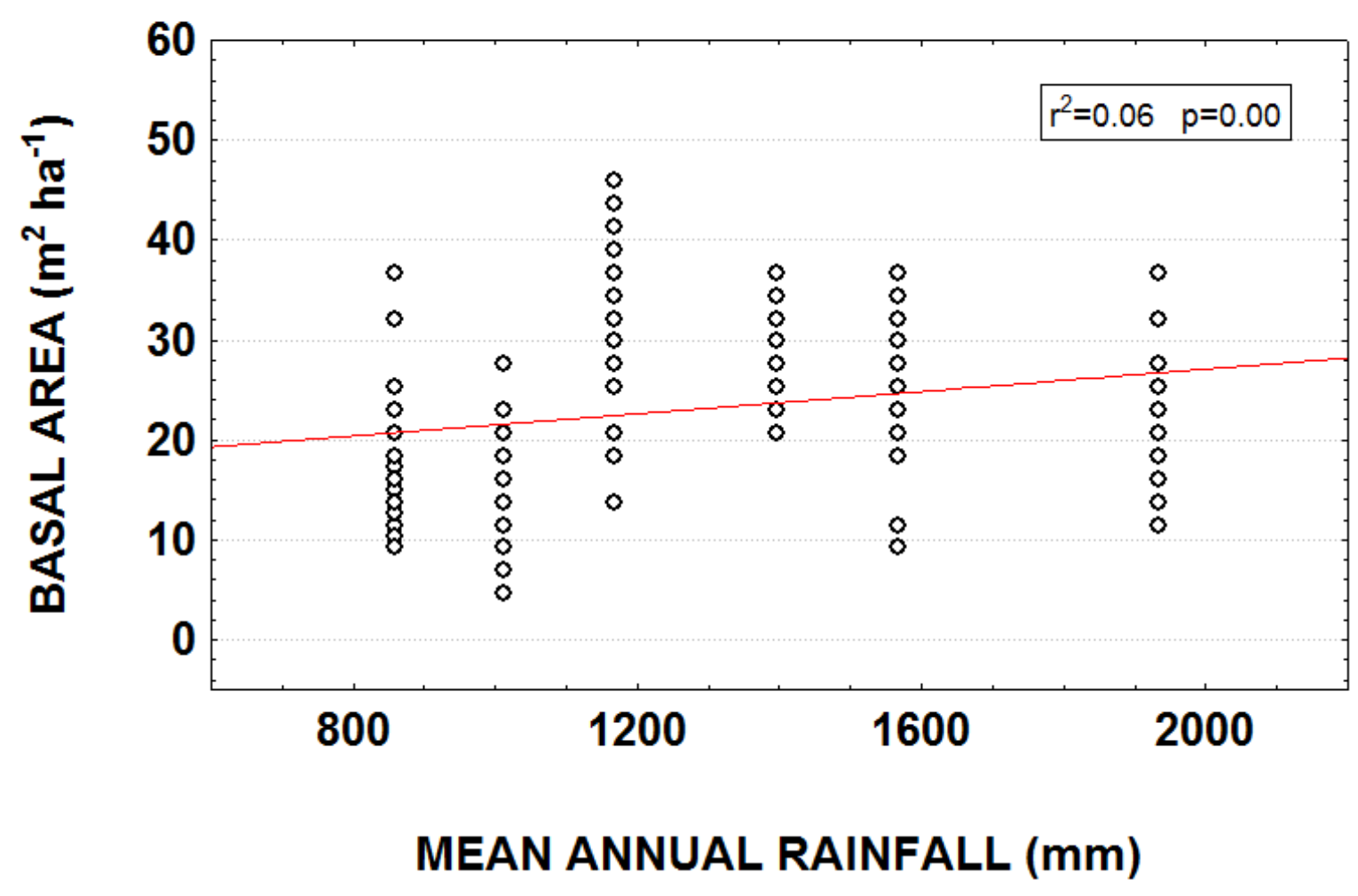

Figure 8. Scatterplot showing the effect of rainfall on basal area 


\section{ECOSITES SOILO TOTAL NITROGEN}

- Mean I Mean \pm SE

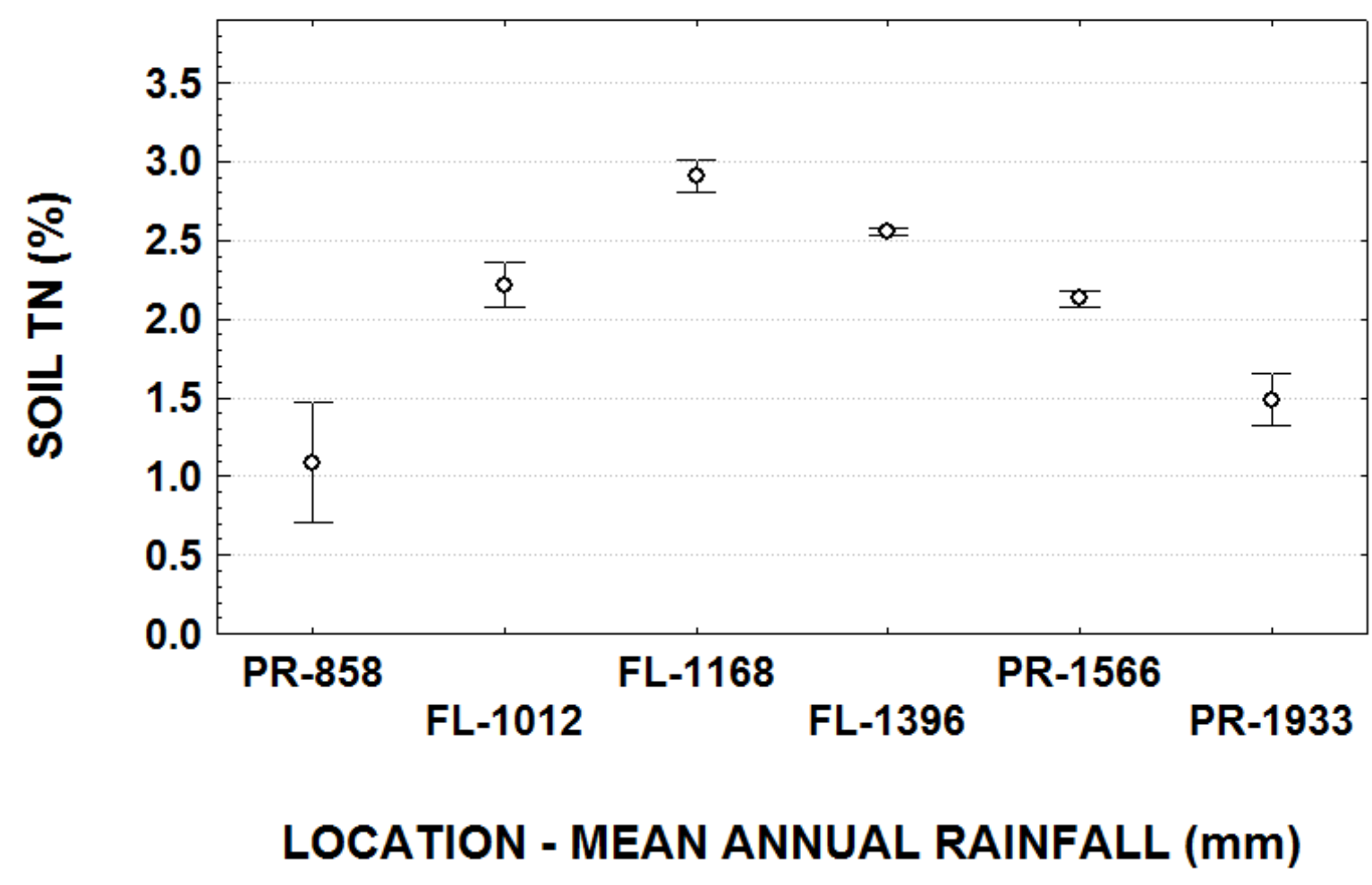

Figure 9. Means plot of soil total nitrogen in ecosites 


\section{ECOSITES SOIL TOTAL PHOSPHORUS}

- Mean I Mean \pm SE

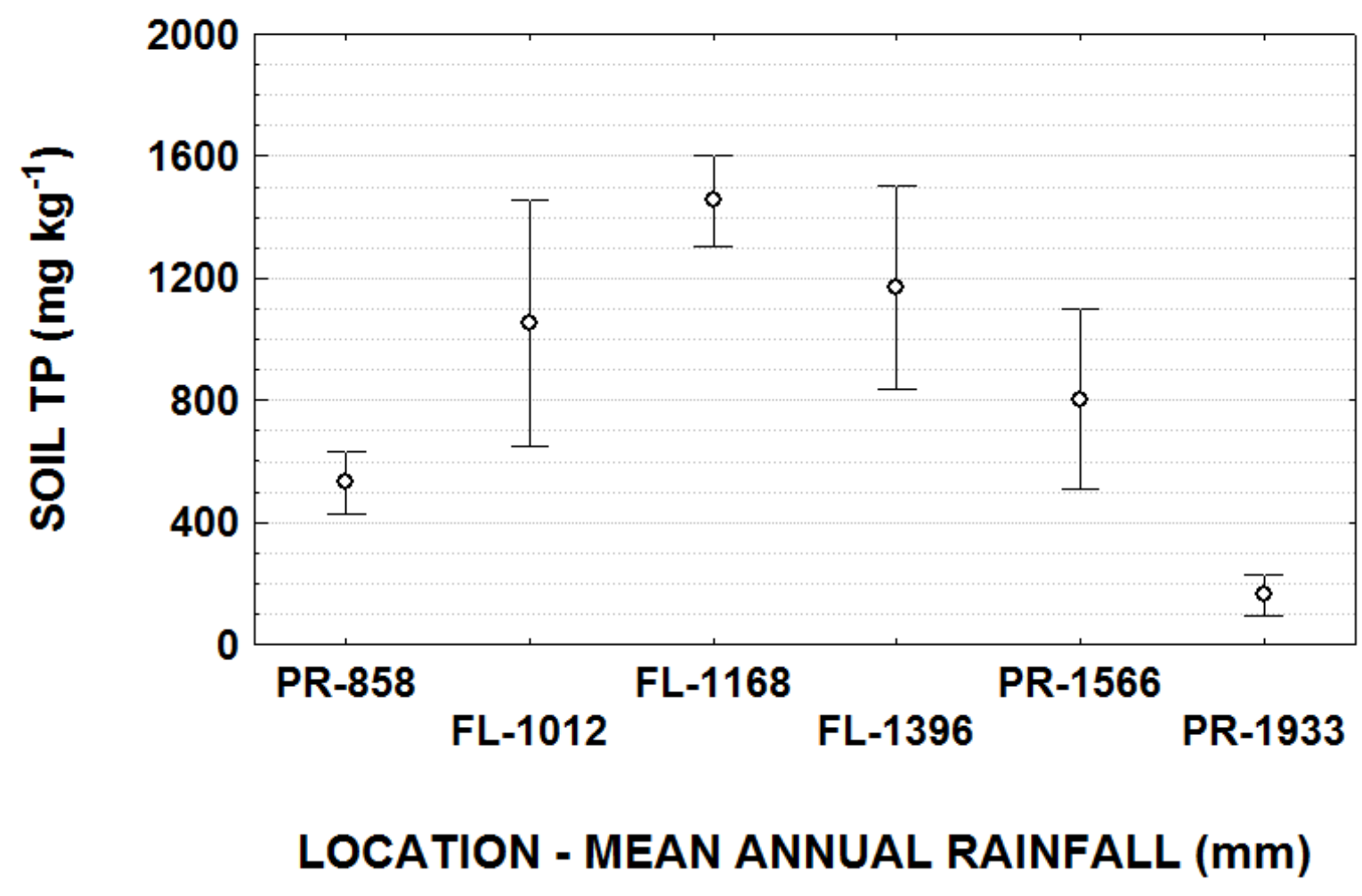

Figure 10. Means plots of soil total phosphorus in ecosites 
ECOSITES SOIL SOLUBLE REACTIVE PHOSPHORUS

- Mean I Mean \pm SE

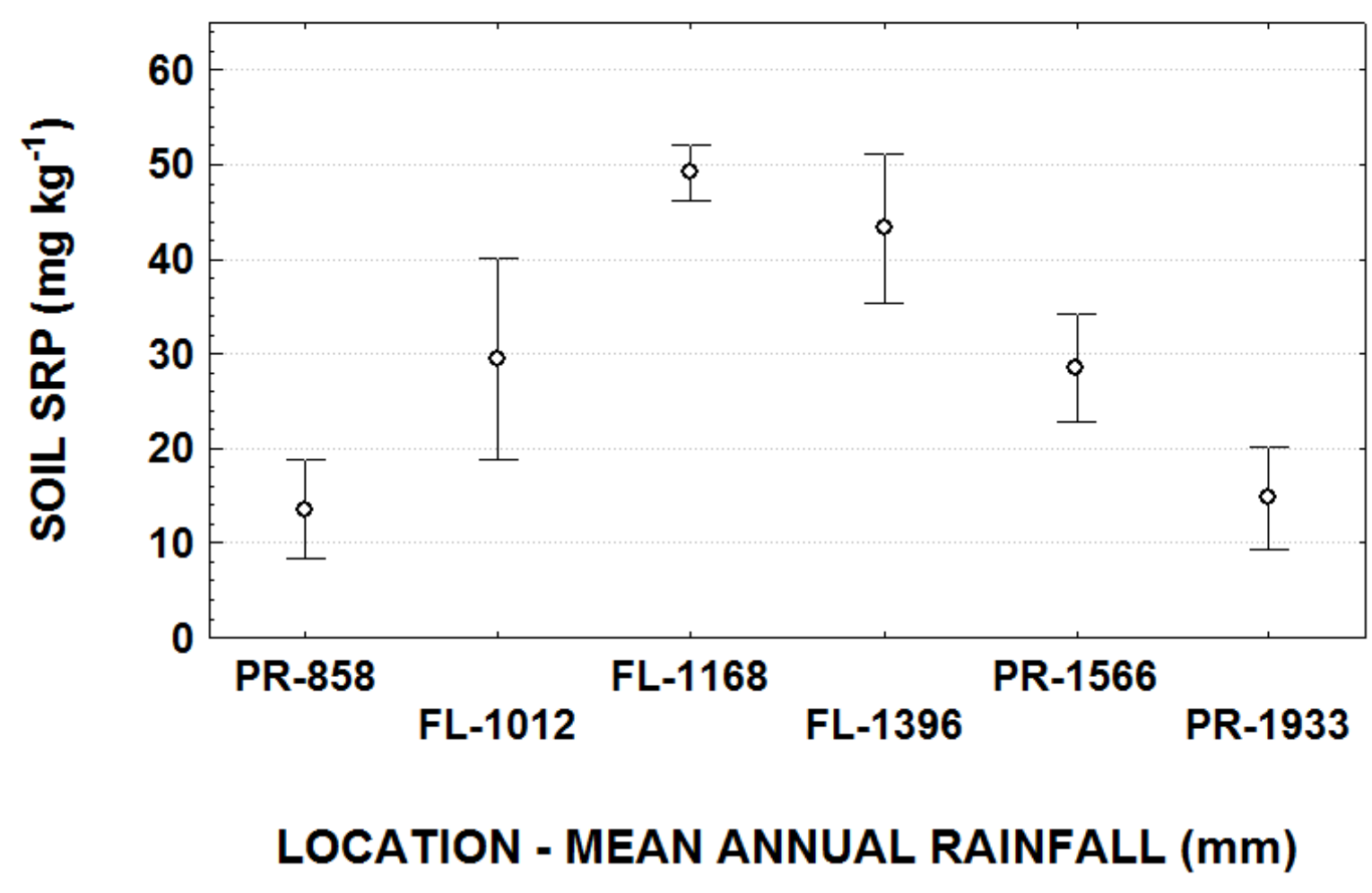

Figure 11. Means plot of soil soluble reactive phosphorus in ecosites 
MEAN ANNUAL RAINFALL VS. SOIL SOLUBLE REACTIVE PHOSPHORUS PERCENTAGE IN TOTAL PHOSPHORUS

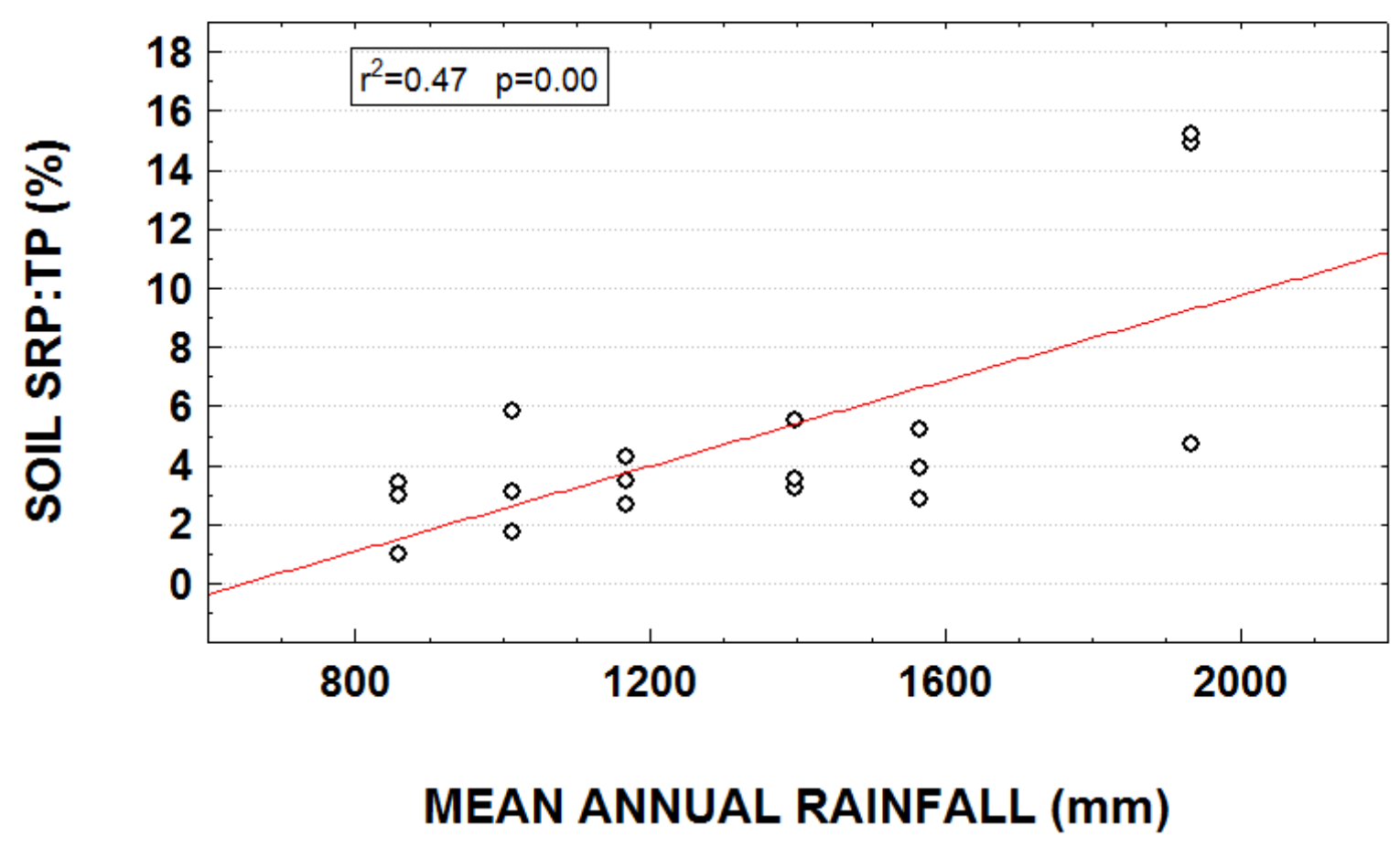

Figure 12. Scatterplot showing the effect of rainfall on soil soluble reactive phosphorus percentage of total phosphorus 


\section{SOIL TOTAL NITROGEN VS. SPECIFIC LEAF AREA}

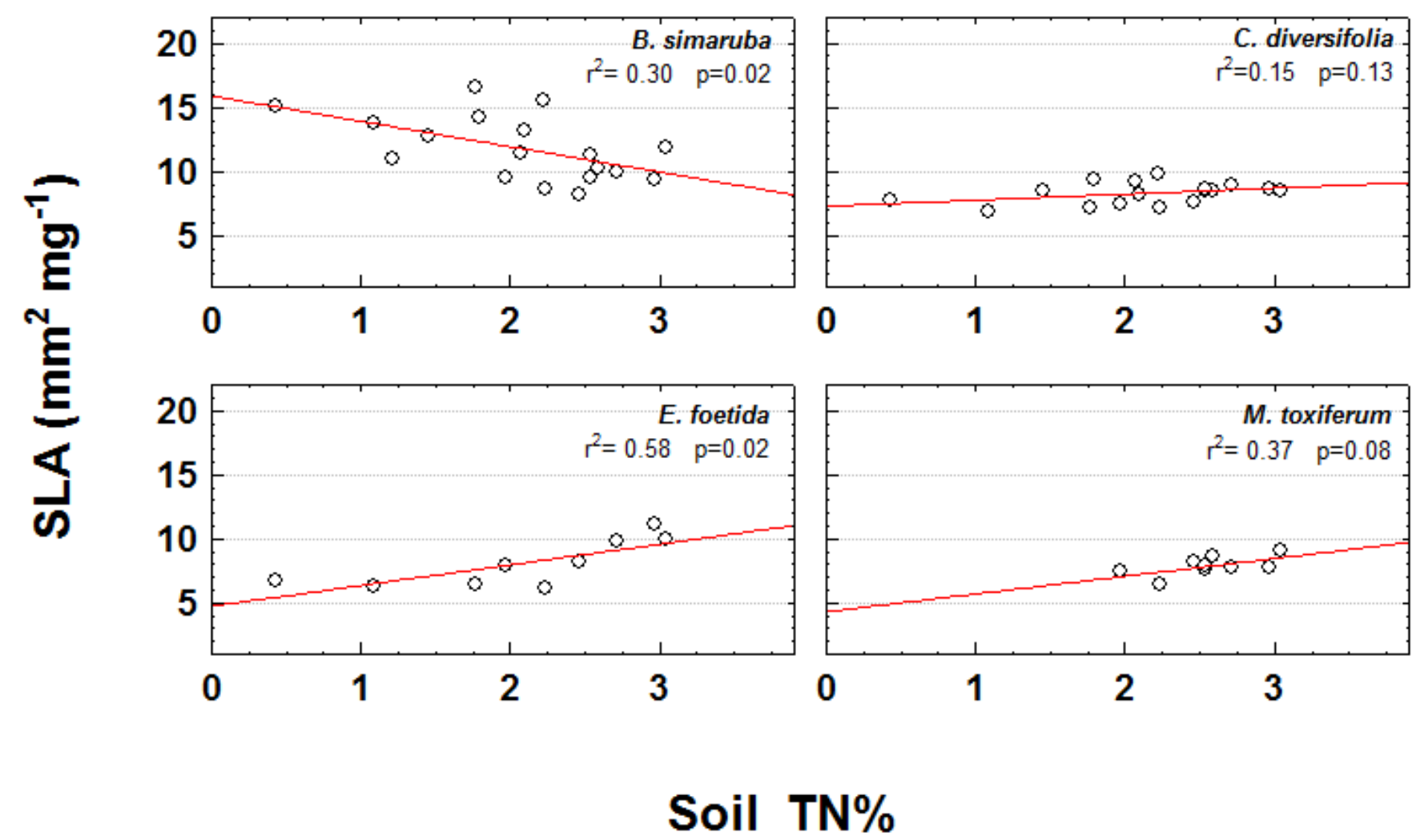

Figure 13. Scatterplot showing the effect of soil total nitrogen on specific leaf area 


\section{SOIL TOTAL NITROGEN VS. LEAF NITROGEN CONTENT}

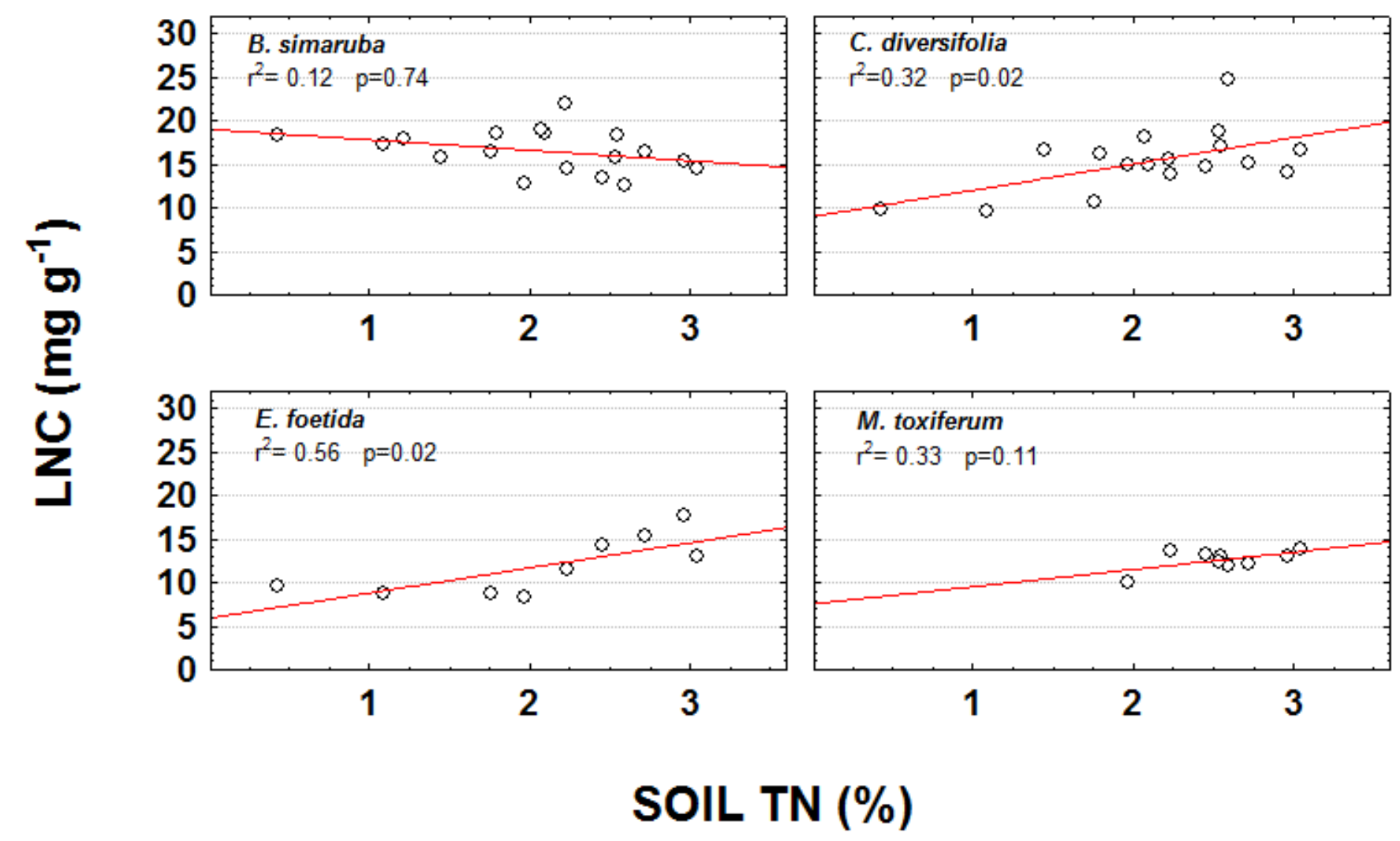

Figure 14. Scatterplot showing the effect of soil total nitrogen on leaf nitrogen on content 


\section{SOIL TOTAL PHOSPHORUS VS.}

\section{LEAF PHOSPHORUS CONTENT}

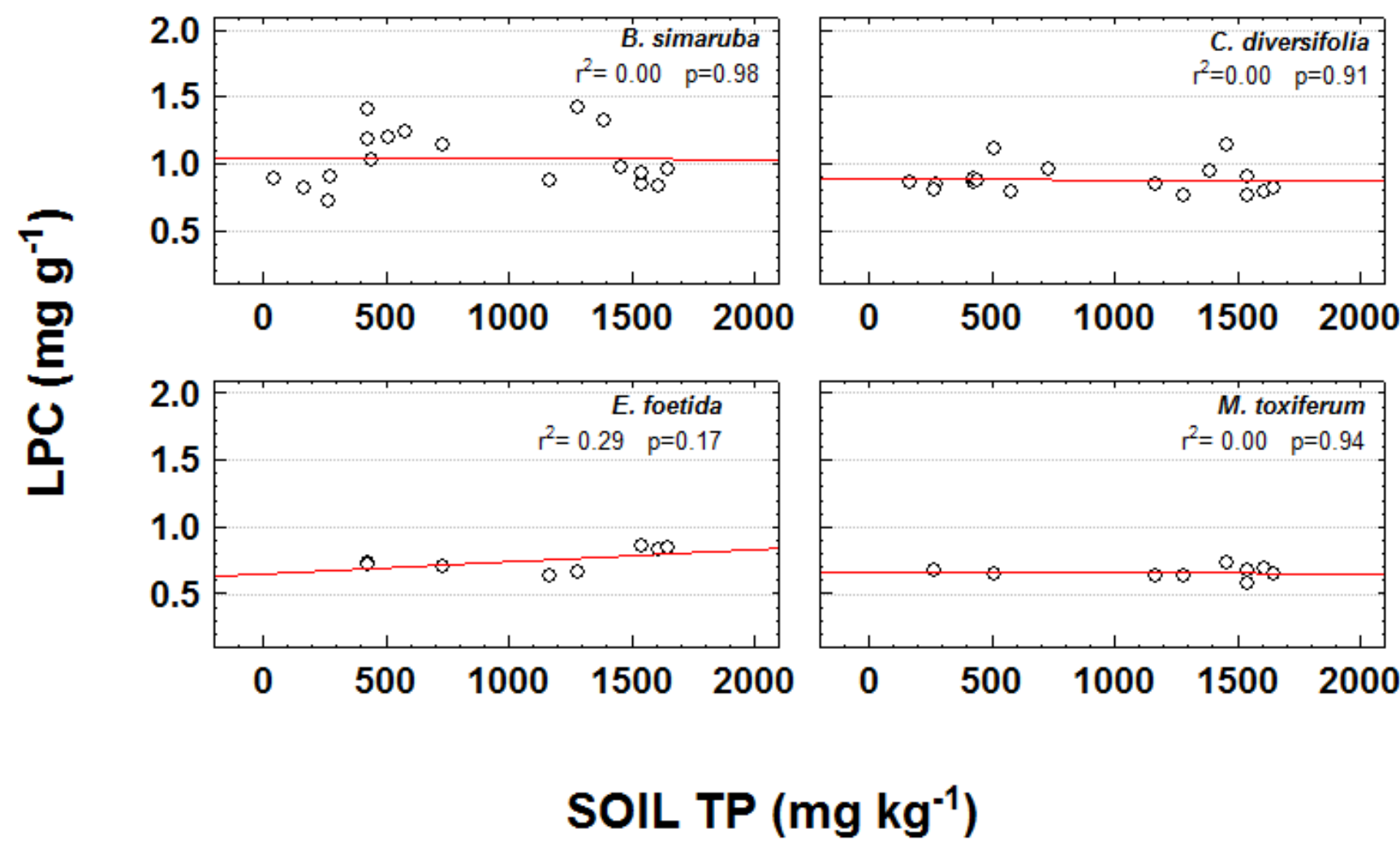

Figure 15. Scatterplot showing the effect of soil total phosphorus on leaf phosphorus content. 
SOIL SOUBLE REACTIVE PHOSPHORUS VS. LEAF PHOSPHORUS CONTENT

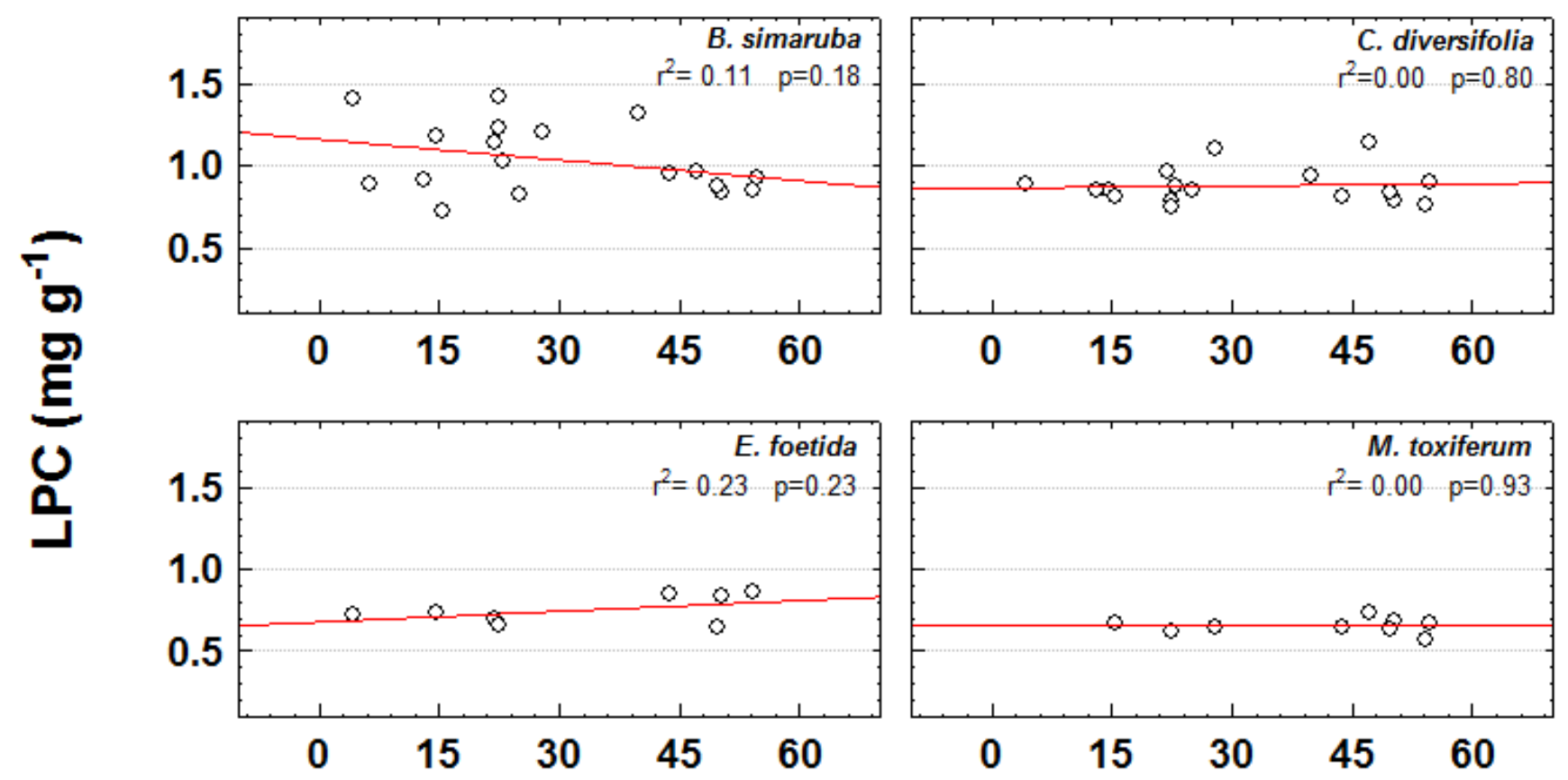

SOIL SRP $\left(\mathrm{mg} \mathrm{kg}^{-1}\right)$

Figure 16. Scatterplot showing the effect of soil soluble reactive phosphorus on leaf phosphorus content 